\title{
Excess mortality from mental, neurological and substance use disorders in the Global Burden of Disease Study 2010
}

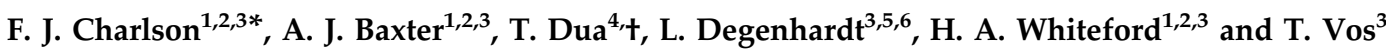 \\ ${ }^{1}$ Queensland Centre for Mental Health Research, Wacol, Queensland, Australia \\ 2 University of Queensland, School of Population Health, Herston, Queensland, Australia \\ ${ }^{3}$ University of Washington, Institute for Health Metrics and Evaluation, Seattle, Washington, USA \\ ${ }^{4}$ World Health Organization, Department of Mental Health and Substance Abuse, Geneva \\ ${ }^{5}$ University of New South Wales, National Drug and Alcohol Research Centre, New South Wales, Australia \\ ${ }^{6}$ University of Melbourne, Melbourne School of Population and Global Health, Victoria, Australia
}

\begin{abstract}
Aims. Mortality-associated burden of disease estimates from the Global Burden of Disease 2010 (GBD 2010) may erroneously lead to the interpretation that premature death in people with mental, neurological and substance use disorders (MNSDs) is inconsequential when evidence shows that people with MNSDs experience a significant reduction in life expectancy. We explore differences between cause-specific and excess mortality of MNSDs estimated by GBD 2010.

Methods. GBD 2010 cause-specific death estimates were produced using the International Classification of Diseases death-coding system. Excess mortality (all-cause) was estimated using natural history models. Additional mortality attributed to MNSDs as underlying causes but not captured through GBD 2010 methodology is quantified in the comparative risk assessments.
\end{abstract}

Results. In GBD 2010, MNSDs were estimated to be directly responsible for 840000 deaths compared with more than 13 million excess deaths using natural history models.

Conclusions. Numbers of excess deaths and attributable deaths clearly demonstrate the high degree of mortality associated with these disorders. There is substantial evidence pointing to potential causal pathways for this premature mortality with evidence-based interventions available to address this mortality. The life expectancy gap between persons with MNSDs and the general population is high and should be a focus for health systems reform.

Received 28 September 2014; Revised 2 October 2014; Accepted 4 October 2014; First published online 15 December 2014

Key words: Global burden of disease, mental health, mortality, neuropsychiatry.

\section{Introduction}

Findings from the Global Burden of Disease 2010 (GBD 2010) study have reinforced our understanding of the significant impact that mental, neurological and substance use disorders (MNSDs) have on population health (Murray et al. 2012; Whiteford et al. 2013). One of the key findings of GBD 2010 was the global health transition from communicable to noncommunicable diseases and this is particularly rapidly in low- and middle-income countries (LMICs) (Murray

* Address for correspondence: F. Charlson, Queensland Centre for Mental Health Research, Locked bag 500, Sumner Park BC, Qld 4074, Australia.

(Email: Fiona_charlson@qcmhr.uq.edu.au)

† Tarun Dua is a staff member of the World Health Organization. The author alone is responsible for the views expressed in this paper and they do not necessarily represent the decisions, policy or views of the World Health Organization. et al. 2012). The proportion of burden attributable to non-communicable disease in LMICs has risen by more than one-third, from $36 \%$ in 1990 to $49 \%$ in 2010. In contrast, the share of non-communicable disease burden in high-income countries (HICs) has raised only $3-4 \%$ over the same time period (from 80 to $83 \%$ ) (Institute of Health Metrics and Evaluation, 2013). These findings hold particular public health importance for MNSDs in LMICs for the coming decades.

GBD 2010 estimates the majority of disease burden due to MNSDs is from non-fatal health loss; only $15 \%$ of the total burden is from mortality, in terms of years of life lost (YLLs) (Institute of Health Metrics and Evaluation, 2013). This may erroneously lead to the interpretation that premature death in people with mental and neurological disorders is inconsequential, whereas evidence shows that people with MNSDs experience a significant reduction in life

This is an Open Access article, distributed under the terms of the Creative Commons Attribution licence (http://creativecommons.org/licenses/by/ $3.0 /)$, which permits unrestricted re-use, distribution, and reproduction in any medium, provided the original work is properly cited. 
expectancy (Chang et al. 2011; Wahlbeck et al. 2011; Crump et al. 2013; Lawrence et al. 2013). In Australia and the UK males with a mental disorder die, on average, 15 years earlier than the general population and females die on average 12 years earlier (Crump et al. 2013; Lawrence et al. 2013). It is estimated that about $80 \%$ of premature deaths in people with MNSDs are due to physical illnesses, particularly cardiovascular disease, including stroke and cancer (Crump et al. 2013; Lawrence et al. 2013). Dementia is an independent risk factor for premature death with increased risk found in those patients with physical impairment and inactivity, and medical comorbidities (Park et al. 2014). Excess mortality in people with epilepsy is reported to be two- to threefold higher compared with the general population; with an increased risk of up to sixfold higher in LMICs (Diop et al. 2005). A significant proportion of these deaths are preventable, resulting from falls, drowning, burns and status epilepticus (Diop et al. 2005; Jette \& Trevathan, 2014). A recent review has shown the highest standardised mortality ratio (SMR) among mental and substance use disorders was 14.7 for opioid use disorders (Chesney et al. 2014). In HICs the life expectancy gap is widening with the general population now enjoying a longer life while the lifespan for those with a mental disorder has remained static (Lawrence et al. 2013).

Mortality associated with a disease can be quantified using two different, yet complementary, methods which are employed as part of GBD analyses. First, cause-specific mortality draws upon vital registration systems and verbal autopsy studies which identify deaths attributed to a single underlying cause using the International Classification of Diseases (ICD) death-coding system. Second, GBD creates natural history models for each disease, including its distribution across age and sex. This involves estimation of a range of epidemiological parameters, including excess mortality - that is, the all-cause mortality rate in a population with the disorder compared with the all-cause mortality rates in a population without the disorder. By definition, estimates of excess deaths include causespecific deaths.

Although often arbitrary, the ICD conventions are a necessary attempt to deal with the multi-causal nature of mortality and avoid 'double-counting' of deaths. However, despite the systems clear strengths, causespecific mortality estimated via the ICD obscures the contribution of other underlying causes of death; for example, suicide as a direct result of major depressive disorder coded as injury, and will likely underestimate the true number of deaths attributable to a particular disease. On the other hand, estimation of excess mortality using natural history models will often comprise deaths from both causal and non-causal origins and will likely overestimate the true number of deaths attributable to a particular disorder. The challenge is to parse out causal contributions to mortality (beyond those already identified as cause-specific) from the effects of confounders.

Quantification of the contributions of multiple causal factors to excess mortality associated with a particular disease is challenging and requires approaches such as the comparative risk assessment (CRA), which is now an integral part of the GBD studies. The fundamental approach for the GBD CRA is to calculate the proportion of deaths or disease burden caused by specific risk factors - e.g., lung cancer caused by tobacco smoking - while holding all other independent factors unchanged. A key concept when attempting to quantify causal relationships is that of 'counterfactual burden' which compares the burden associated with an outcome with the amount that would be expected in a hypothetical situation of 'ideal' risk factor exposure (e.g., zero prevalence). This approach provides a consistent method for estimating the changes in population health as a function of decreasing or increasing the level of exposure to risk factors (Lim et al. 2012). Importantly, the flexibility within counterfactual analysis allows the sum of death counts attributed to different risk factors for a particular cause to sum to more than $100 \%$ which is not permissible by ICD registry data.

In this paper, we explore the cause-specific and excess mortality of individual MNSDs estimated by GBD 2010. We also present the additional attributable burden that can be ascribed to disorders using GBD results for CRA's assessing MNSDs as risk factors for other health outcomes. Disorders included in the analyses are grouped by: mental disorders (schizophrenia, major depression (MDD), anxiety disorders, bipolar disorder, childhood behavioural disorders (attentiondeficit/hyperactivity disorder (ADHD) and conduct disorder (CD)), autistic disorder and intellectual disability); substance use disorders (alcohol, opioid, cocaine and amphetamine use disorders); and neurological disorders (dementia, epilepsy and migraine).

\section{Methods}

\section{YLLs and cause of death}

The GBD 2010 methodology uses a time-based metric, YLLs, to quantify the fatal burden by underlying cause (Lozano et al. 2012). YLLs are computed by multiplying the number of deaths attributable to a particular disease at each age by a standard life expectancy at that age. The standard life expectancy represents the normative goal for survival and for 2010 was computed based on the lowest recorded death rates in 
any age group in countries with a population greater than 5 million (Salomon et al. 2012).

Cause-specific death estimates in GBD 2010 were produced from available cause of death data for 187 countries from 1980 to 2010. Data sources included vital registration, verbal autopsy, mortality surveillance, censuses, surveys, hospitals, police records and mortuaries (Lozano et al. 2012). Cause of death ensemble modelling (CODEm) was used for all MNSDs. In summary, CODEm uses four families of statistical models testing a large set of different models using different permutations of covariates. Model ensembles were developed from these component models and model performance was assessed with rigorous out-of-sample testing of prediction error and the validity of $95 \%$ uncertainty intervals (UIs). Details relating to CODEm and the method for how these models were used in calculating YLLs are described in detail elsewhere (Lozano et al. 2012).

YLLs for GBD 2010 were computed from causespecific mortality estimates for seven of the 15 MNSDs: schizophrenia; opioid, amphetamine, cocaine and alcohol use disorders; dementia and epilepsy (Lozano et al. 2012). As the ICD does not permit the other mental and neurological disorders to be recorded as the 'primary' cause of death, YLLs were unable to be calculated for the remaining eight disorder groups (World Health Organization, 1993; Lim et al. 2012).

\section{Excess mortality from a natural history model}

Drawing on a series of systematic reviews, we collated comprehensive sets of epidemiologic data for each disorder. Data were pooled, adjusting for between-study variance, and then an internally consistent epidemiologic model derived using the relationship described in the generic disease model (see the appendix) (Vos et al. 2012). To do this we used DisMod-MR, a Bayesian meta-regression tool which estimates a natural history of disease model producing age-, sex- and region-specific estimates for prevalence, incidence, remission and excess mortality (Vos et al. 2012). Where data were scarce, DisMod-MR was able to impute information with associated uncertainty ranges based on epidemiologically and geographically similar populations. Excess mortality estimates based on this natural history model are reported for MNSDs in terms of global deaths for 2010. Further details of the GBD 2010 methods for developing a natural history model of disease using DisMod-MR have been described in detail elsewhere (Vos et al. 2012).

\section{Counter-factual burden and CRA}

Prince et al. (2007) have summarised the evidence where a causal relationship between mental and substance use disorders and other health outcomes have been proposed. In GBD 2010, a series of reviews were conducted to assess the strength of evidence for MNSDs as independent risk factors for other health outcomes (Degenhardt et al. 2009a; Rehm et al. 2010a; Charlson et al. 2011; Degenhardt \& Hall, 2012). Risk factor studies were identified through systematic searches of published and unpublished data with information on effect sizes and study characteristics extracted and collated (Charlson et al. 2013; Degenhardt et al. 2013; Ferrari et al. 2014). A metasynthesis was used to calculate a relative risk (RR) for MNSDs (the exposure) as a risk factor for other health outcomes. The RR was then applied to prevalence distributions of the specific exposures by sex and age-group for each geographic region to derive population attributable fractions (PAFs). More detail on the calculation of PAFs in GBD 2010 is provided by Lim et al. (2012). In some cases, for example suicide, ceiling values were calculated and applied for joint PAFs to ensure the sum of proportional contribution for all risk factors did not exceed $100 \%$ (Ferrari et al. 2014). The additional burden (YLLs and YLDs) attributable to MNSDs is the product of the PAFs and the burden for the health outcome as estimated in GBD 2010.

Here we compare the number of cause-specific deaths reported (YLLs) for MNSDs, calculated as part of the GBD 2010 study with the number of allcause deaths derived from natural history models. We explore differences in these estimates across the age-span for each disorder. Additional YLLs attributed to disorders as underlying causes and quantified in the CRA are reported.

\section{Results}

\section{YLLs and causal mortality}

Globally, the seven disorders (dementia, epilepsy, schizophrenia, alcohol use disorders, opioid use disorders, cocaine use disorders and amphetamine use disorders) for which YLLs were estimated were directly responsible for 1.3 million deaths in 2010, equating to about 12 million YLLs (see Fig. 2 in the appendix). Epilepsy and then dementia contributed the greatest proportion of YLLs within this group.

Age-standardised YLL rates vary considerably across the seven geographical super-regions primarily due to differences in patterns of alcohol and drug use, and mental and neurological disorder prevalence. There are several regions with substantial deviations from global YLL average rates (Fig. 1). (Details of which countries are in each sup-region can be found 


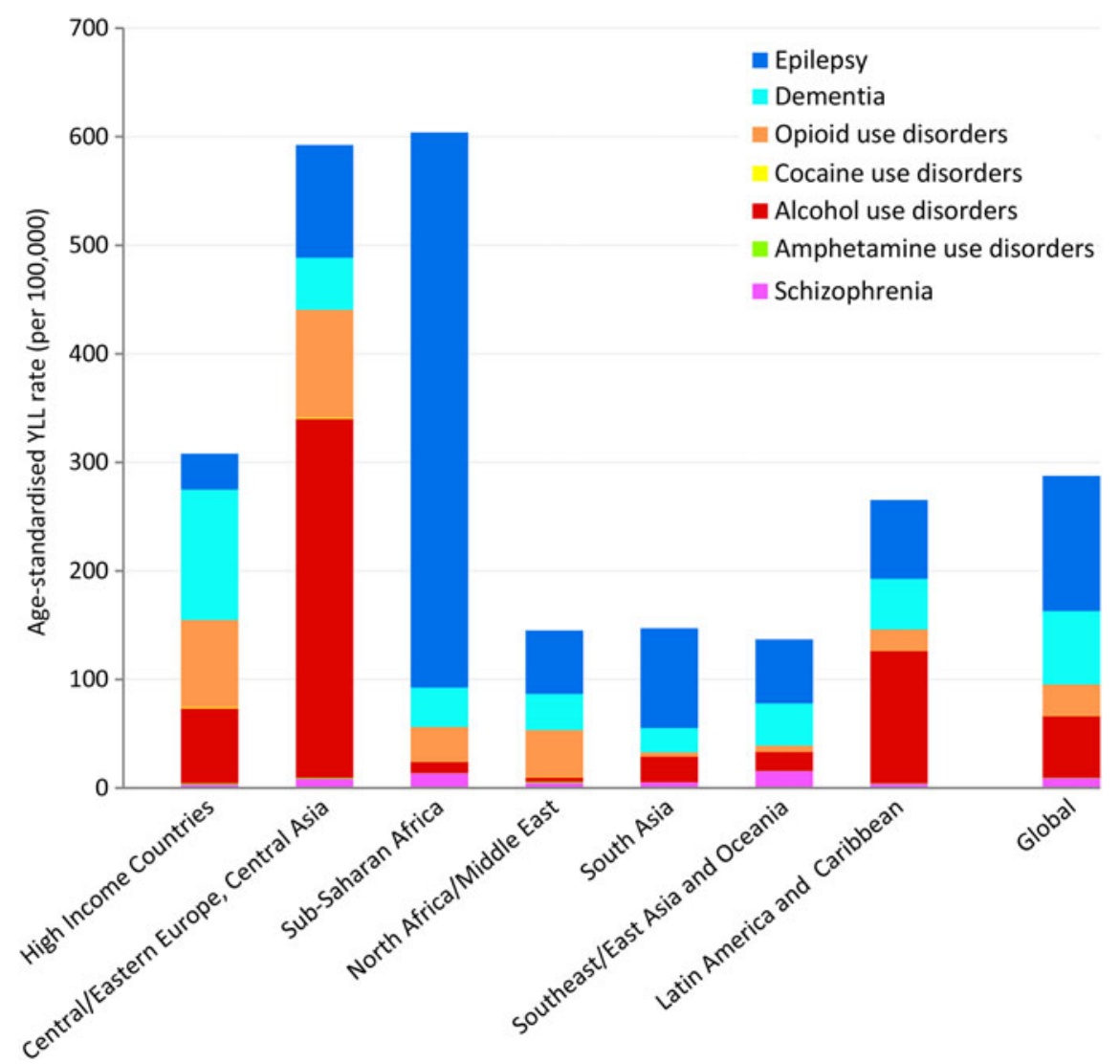

Fig. 1. Age-standardised YLL rates (per 100000 population) for MNSDs by GBD super-region and disorder, 2010.

on the IHME website (Institute for Health Metrics and Evaluation, 2014).)

In 2010, YLL rates were highest in the sub-Saharan Africa region (604 YLLs per 100000 population) and the region comprising Central/Eastern Europe plus Central Asia (593 YLLs per 100 000); the causes for which vary considerably (Fig. 1). In sub-Saharan Africa the YLL burden was driven by epilepsy which was fourfold higher than the global average and approximately $85 \%$ of all YLLs attributed to MNSDs in sub-Saharan Africa. Although the substance use disorders YLL rates appear unremarkable for this region, their YLL burden has increased 3.0\% from 1990 to 2010, almost double the average global increase and the highest of all regions (Degenhardt et al. 2013). In contrast to sub-Saharan Africa, the high fatal burden in Central/Eastern Europe and Central Asia was largely caused by deaths attributed to alcohol use. High mortality due to illicit substance use disorders also contributed to the YLL rate in Central/Eastern Europe and Central Asia with all substance use disorders together explaining $73 \%$ of YLLs in the region. Countries within East Asia and the Pacific exhibit very low YLL rates across all MNSDs with little change observed between 1990 and 2010.
Globally, neurological disorders accounted for 58\% of the all MNSD YLLs in males and $81 \%$ of YLLs in females. Substance use disorders explained $39 \%$ of YLLs in males and $16 \%$ of those in females. The contribution of schizophrenia to total MNS disorder YLLs was similar for both genders (3\% each). Differences in YLL patterns between the genders were influenced in part by the differing contribution to YLLs by substance use disorders compared with neurological disorders across regions (Fig. 2).

\section{Excess mortality from a natural history model}

The only mental disorder for which cause-specific deaths and YLLs were estimated in GBD was schizophrenia; however, several mental disorders, such as major depression and bipolar disorder, exhibit significant and documented excess-mortality (Roshanaei-Moghaddam \& Katon, 2009; Baxter et al. 2011b) (Table 1). There were four disorders for which sufficient evidence of excess all-cause mortality could not be found in the literature (anxiety, childhood behavioural disorders, cannabis dependence and migraine) and therefore excess mortality was not included in the natural history of disease for these disorders. 


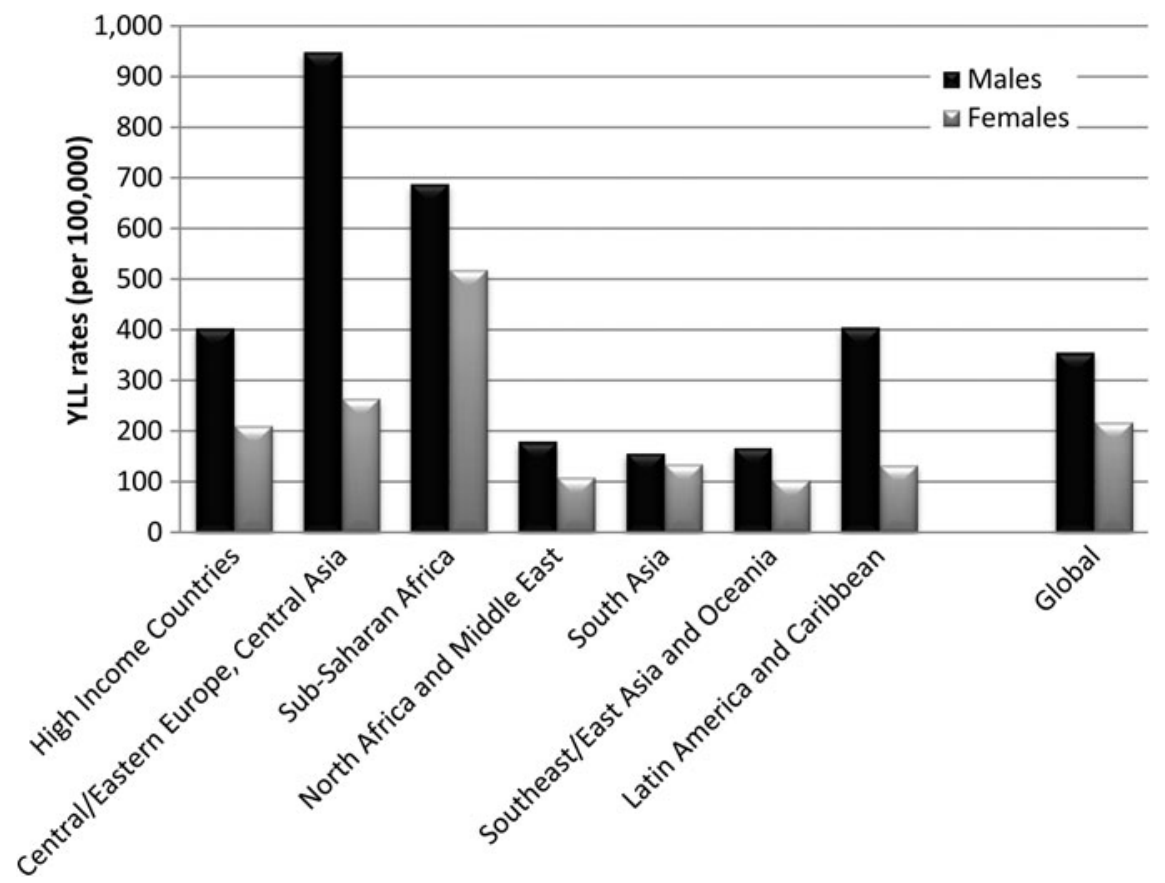

Fig. 2. Age-standardised YLL rates (per 100 000) for MNSDs by GBD super-region and sex, 2010.

\section{Mental disorders}

Figure 3 shows the estimated number of cause-specific and excess deaths for each of the five mental disorders with estimated excess mortality by age and with uncertainty bounds. While cause-specific deaths were attributed to only one mental disorder (schizophrenia), excess mortality was present in natural history models for five: schizophrenia, bipolar disorder, MDD, autistic disorder and intellectual disability.

Although schizophrenia is one of the few mental disorders with cause-specific deaths permissible by ICD,

Table 1. Presence of cause-specific mortality and excess mortality attributed to DCP3 MNSDs in GBD 2010

Disorders

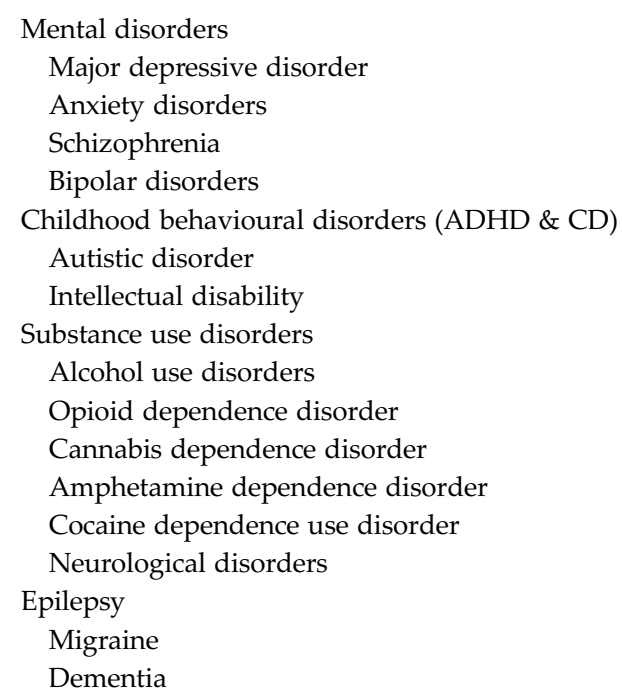




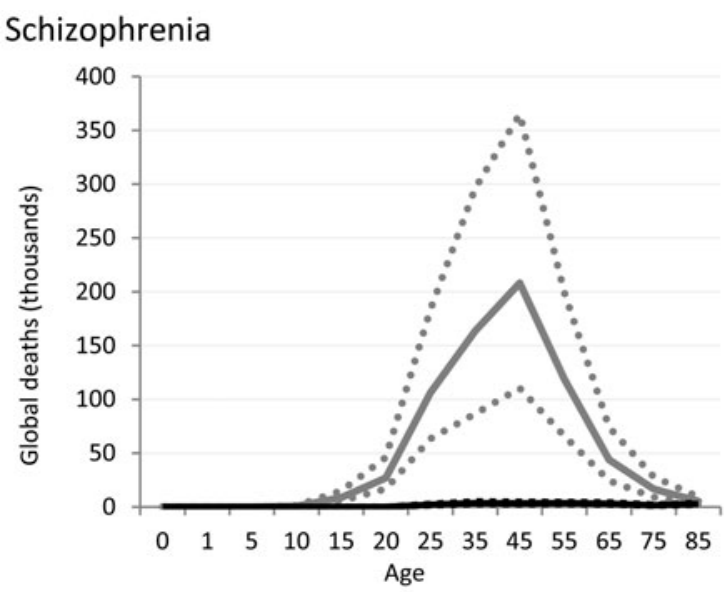

Autistic disorder

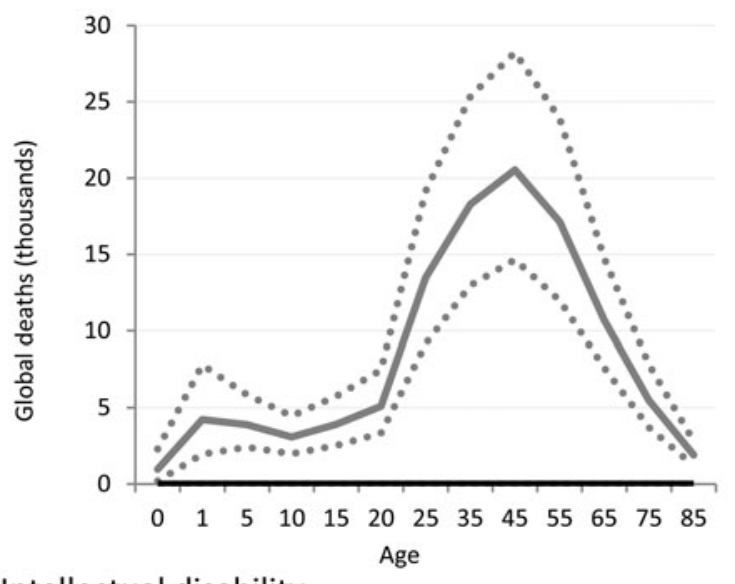

Intellectual disability

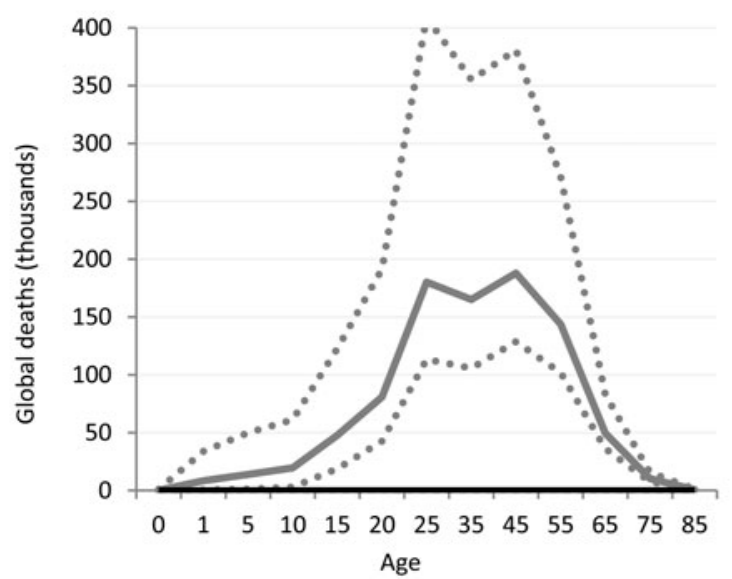

Bipolar disorder

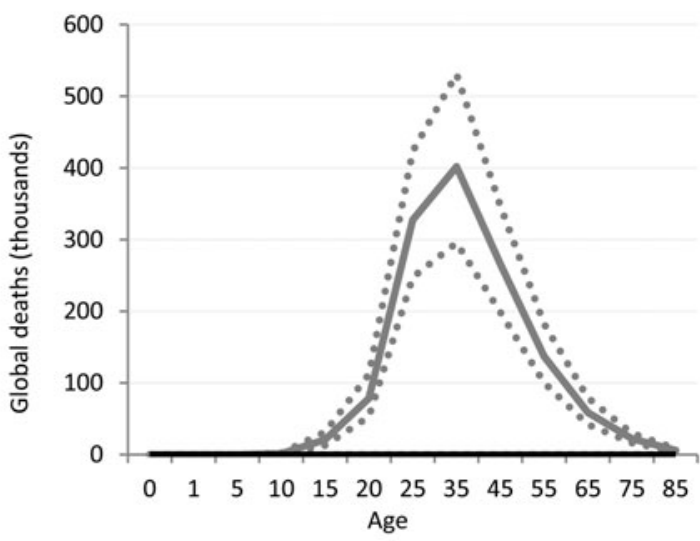

Major depressive disorders

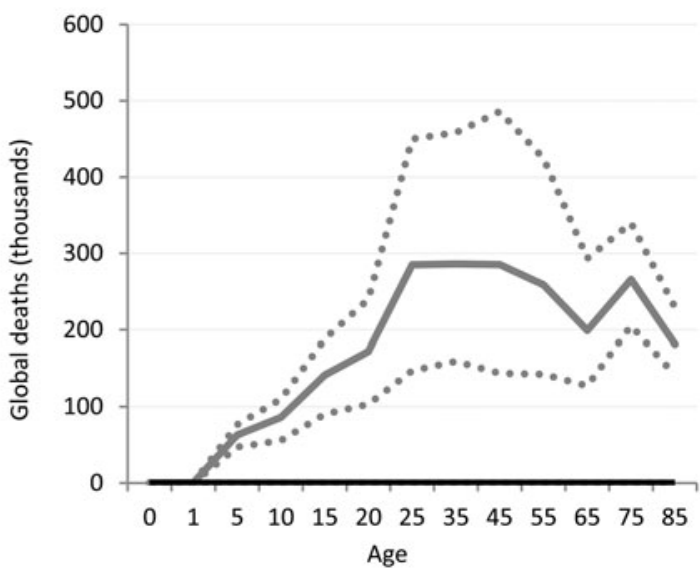


disorders in GBD 2010. Natural history models of MDD suggest there were more than 2.2 million excess deaths in persons with MDD, with a particularly high rate of death in older persons that is not observed in schizophrenia or bipolar disorder.

Intellectual disability was modelled as an 'envelope disorder' for GBD 2010, meaning that the intellectual disability ascribed to all underlying causes including meningitis, Down's syndrome, and chromosomal defects, were captured under a single disorder category. After modelling, the contributions of each specific underlying cause were separated out and a 'rest' category of idiopathic intellectual disability was created. There were no deaths causally attributed to intellectual disability; however, excess deaths in people with idiopathic intellectual disability were estimated to be substantial at over 900000 deaths globally in 2010 .

At this time there is insufficient information available to determine whether premature mortality is significantly raised across the spectrum of anxiety disorders (Baxter et al. 2014) and in childhood behavioural disorders (Erskine et al. 2013). In GBD 2010 there were no YLLs or excess mortality associated with the natural history of disease applied to anxiety disorders or childhood behavioural disorders.

\section{Substance use disorders}

GBD estimates indicate more than 110000 deaths were causally attributed to alcohol use disorders worldwide in 2010, but indicative of the true impact of alcohol dependence as an underlying cause of death in many is that over 5 million excess deaths were estimated in the same year. Over 700000 excess deaths occurred in dependent illicit drug users in 2010 compared with only 44000 deaths which were coded as the cause of death. The majority of these deaths can be ascribed to opioid dependence (43 000) (Fig. 4).

\section{Neurological disorders}

Cause-specific death estimates are more substantial for neurological disorders (Fig. 5) resulting in a less
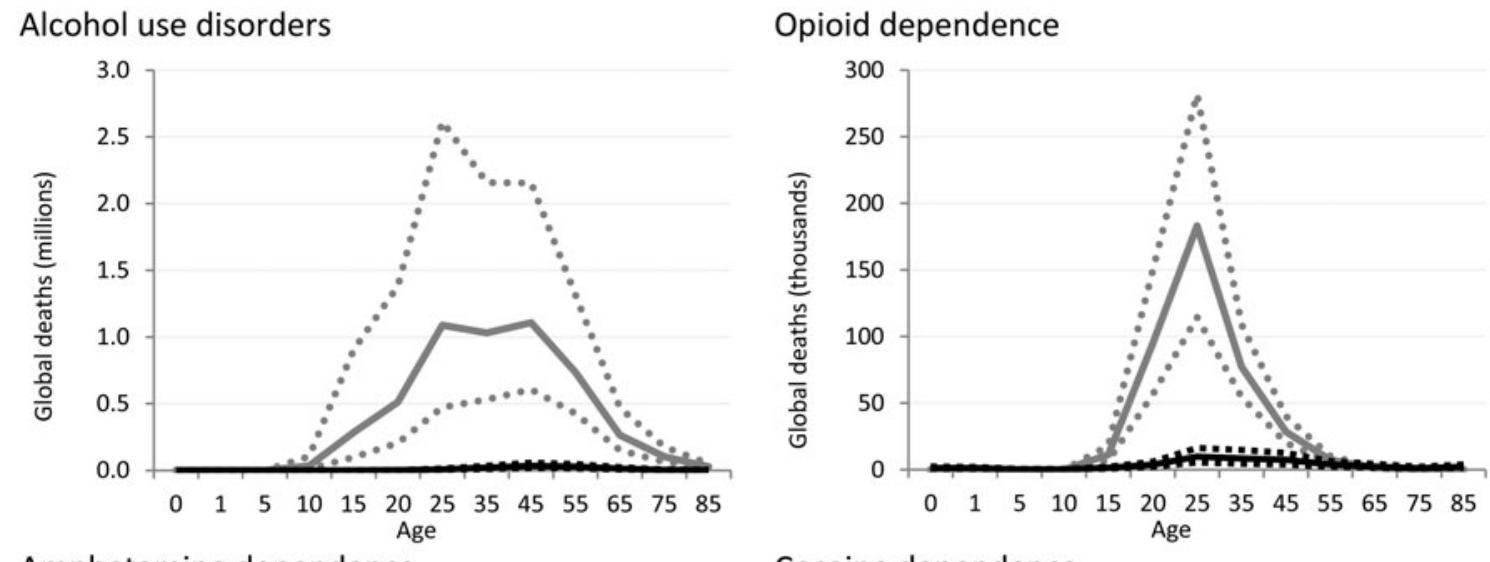

Amphetamine dependence

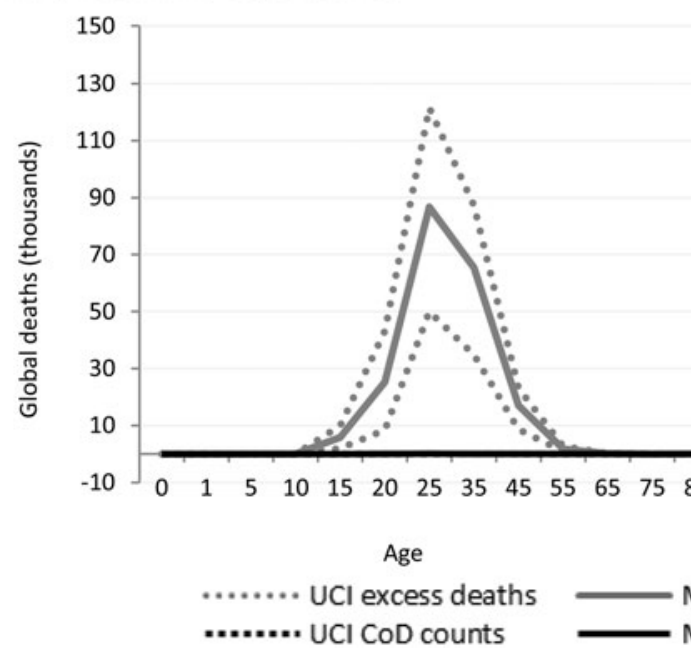

Cocaine dependence

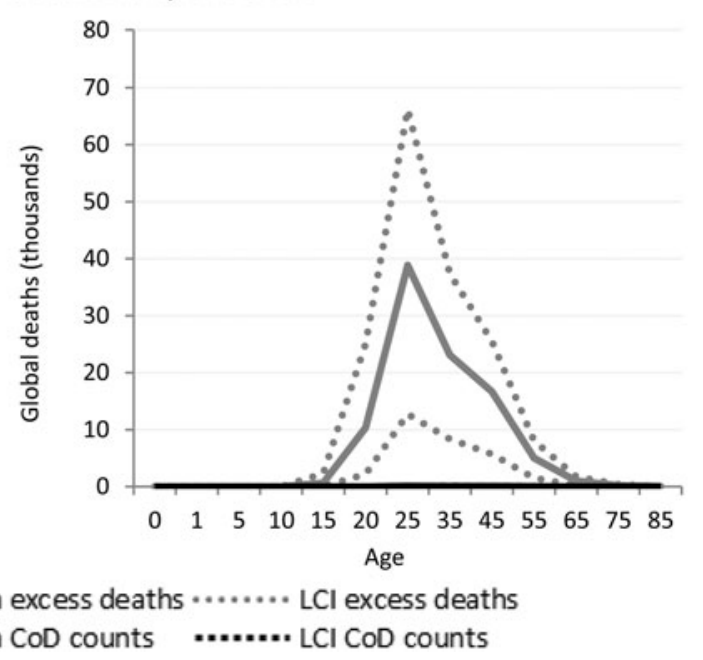

Fig. 4. Numbers of cause-specific and excess deaths attributed to substance use disorders in 2010, by age and with upper and lower $95 \%$ CI. *Note: Cannabis not shown as there was no cause-specific or excess mortality. 


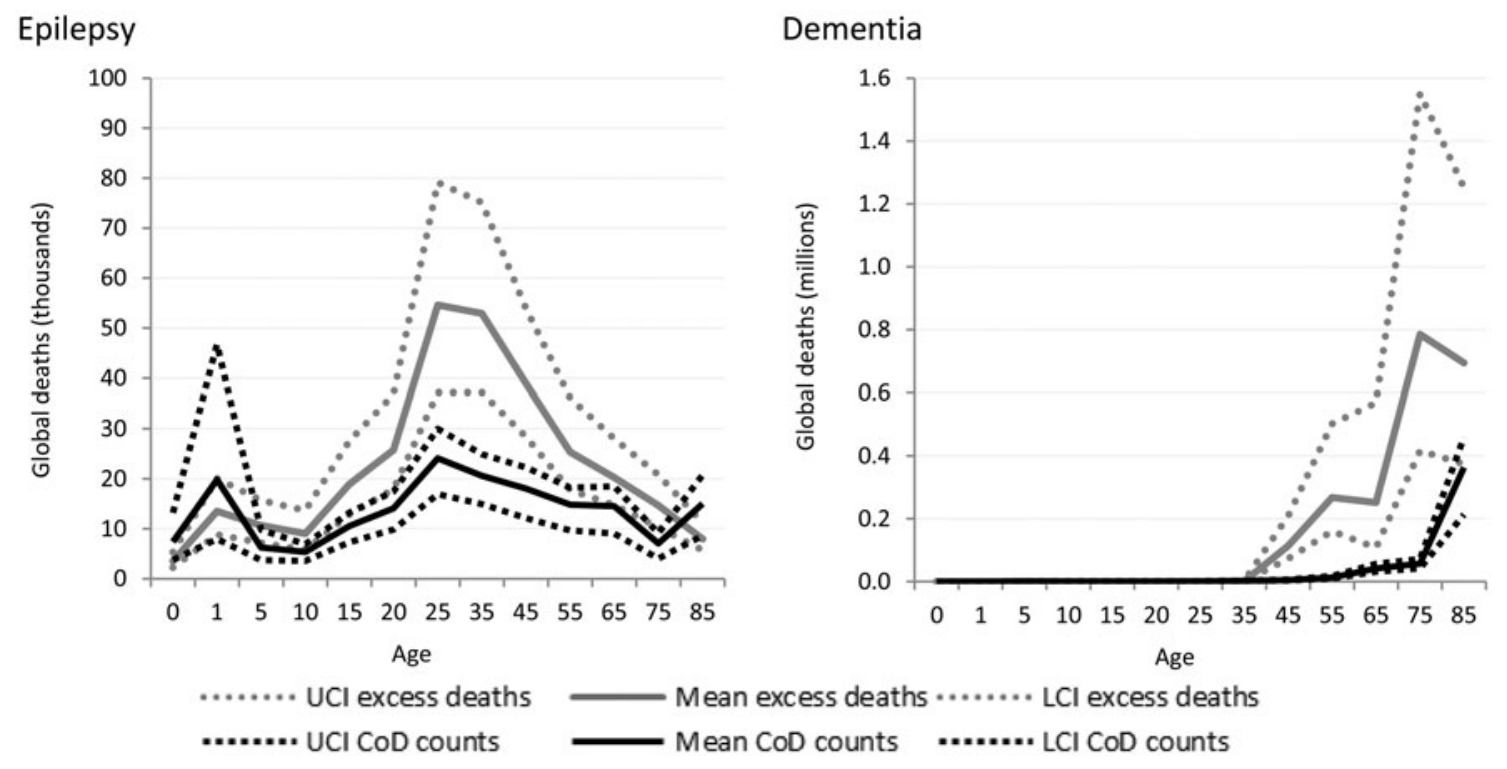

Fig. 5. Numbers of cause-specific and excess deaths attributed to neurological disorders in 2010, by age and with upper and lower $95 \%$ CI. *Note: Migraine not shown as there was no cause-specific or excess mortality.

dramatic gap between cause-specific and excess deaths. This is likely indicative of neurological disorders being recognised more readily as the primary cause of death.

Similar to intellectual disability, epilepsy was modelled as an envelope disorder in GBD 2010 with idiopathic epilepsy and epilepsy secondary to a range of causes, including meningitis, neonatal tetanus, iodine deficiency and a variety of birth complications, being modelled as one disorder. Cause of death modelling estimated nearly 180000 deaths due to epilepsy in 2010 while natural history models show us about 300000 excess deaths in fact took place. The proportion of deaths attributable to different causes differ by region and GBD 2010 showed sub-Saharan African populations had the highest death rate due to epilepsy. Around 2.1 million excess deaths worldwide were estimated from dementia for 2010, yet less than 500000 were attributed to dementia as the primary cause of death.

Table 2 shows that the cause-specific deaths and excess deaths directly coded to MNSDs are relatively similar up to 4 years of age but then rise sharply: in children aged 5-9 years there were 7420 cause-specific deaths compared with more than 91000 excess deaths in the same age group. Alcohol use disorders explained the highest number of excess deaths (5.2 million): $38 \%$ of all excess deaths due to mental and neurological disorders in 2010. Considered together, the mental disorders for which no cause-specific deaths were attributed (bipolar disorder, major depression, autism and intellectual disability) explained more than 4.5 million deaths, equating to one third of all excess deaths in 2010.

\section{Counter-factual burden and CRA}

The reviews conducted as part of GBD 2010 collectively yielded sufficient evidence for several CRAs (see Table 3). Neurological disorders were not assessed as risk factors in GBD 2010.

For mental disorders, a number of associations were investigated but data limitations meant that only suicide and IHD were able to be included as outcomes for mental disorders (suicide) and MDD (IHD) (Baxter et al. 2011a; Charlson et al. 2011; Ferrari et al. 2014). Collectively, mental and substance use disorders are estimated to be responsible for about 22 million YLLs due to death by suicide (Ferrari et al. 2014). The CRA of major depression as a risk factor for ischaemic heart disease estimated an attributable to burden of about 3.5 million YLLs (Charlson et al. 2013).

Injecting drug use was considered as a risk factor for a number of outcomes, including blood borne viruses and liver disease, and collectively accounted for over 7 million YLLs in attributable burden. Interestingly, and despite common preconceptions, GBD results did not show any mortality-related burden from schizophrenia that could be attributed to cannabis dependence. Alcohol use was the biggest contributor with nearly 80 million attributable YLLs estimated across a number of health outcomes.

Figure 6 shows the considerable additional burden when MNSDs are considered as underlying 
Table 2. Number of cause-specific and excess deaths, by age for 2010

\begin{tabular}{|c|c|c|c|c|c|c|c|c|c|c|c|c|c|}
\hline & $\begin{array}{c}0-1 \\
\text { years }\end{array}$ & $\begin{array}{c}1-4 \\
\text { years }\end{array}$ & $\begin{array}{c}5-9 \\
\text { years }\end{array}$ & $\begin{array}{l}10-14 \\
\text { years }\end{array}$ & $\begin{array}{l}15-19 \\
\text { years }\end{array}$ & $\begin{array}{l}20-24 \\
\text { years }\end{array}$ & $\begin{array}{l}25-34 \\
\text { years }\end{array}$ & $\begin{array}{l}35-44 \\
\text { years }\end{array}$ & $\begin{array}{l}45-54 \\
\text { years }\end{array}$ & $\begin{array}{l}55-64 \\
\text { years }\end{array}$ & $\begin{array}{l}65-74 \\
\text { years }\end{array}$ & $75+$ years & Total \\
\hline \multicolumn{14}{|l|}{ Cause-specific deaths } \\
\hline $\begin{array}{l}\text { Alzheimer's disease and } \\
\text { other dementias }\end{array}$ & - & - & 869 & 605 & 578 & 642 & 1259 & 2302 & 4575 & 12559 & 41622 & 420710 & 485721 \\
\hline Epilepsy & 7388 & 19819 & 6255 & 5351 & 10562 & 14101 & 24107 & 20605 & 18038 & 14826 & 14522 & 22054 & 177627 \\
\hline Schizophrenia & - & - & - & - & - & - & 2003 & 3610 & 3429 & 3440 & 3035 & 4246 & 19763 \\
\hline Alcohol use disorders & - & - & - & - & 464 & 1311 & 7937 & 20044 & 33613 & 27446 & 13295 & 7024 & 111134 \\
\hline Opioid use disorders & 1231 & 1217 & 288 & 260 & 1350 & 3745 & 9736 & 8446 & 7432 & 3846 & 2319 & 3171 & 43040 \\
\hline Cocaine use disorders & 13 & 12 & 3 & 3 & 16 & 47 & 120 & 107 & 96 & 53 & 33 & 44 & 549 \\
\hline $\begin{array}{l}\text { Amphetamine use } \\
\text { disorders }\end{array}$ & 13 & 11 & 3 & 3 & 14 & 40 & 102 & 88 & 75 & 44 & 30 & 41 & 465 \\
\hline Total & 8644 & 21059 & 7420 & 6222 & 12984 & 19886 & 45263 & 55201 & 67258 & 62214 & 74856 & 457291 & 838299 \\
\hline \multicolumn{14}{|l|}{ Excess deaths } \\
\hline $\begin{array}{l}\text { Alzheimer's disease and } \\
\text { other dementias }\end{array}$ & - & - & - & - & - & - & - & 1160 & 114334 & 267613 & 251719 & 1478957 & 2113783 \\
\hline Epilepsy & 3513 & 13486 & 10680 & 9050 & 18957 & 25784 & 54590 & 52928 & 38961 & 25330 & 20276 & 22647 & 296201 \\
\hline Schizophrenia & - & - & - & 816 & 8758 & 26990 & 106121 & 163634 & 208056 & 118828 & 43846 & 21945 & 698993 \\
\hline Alcohol use disorders & - & - & - & 33178 & 285509 & 512200 & 1088632 & 1030419 & 1107039 & 734711 & 265061 & 130643 & 5187391 \\
\hline Opioid use disorders & - & - & - & - & 11268 & 94748 & 183102 & 77352 & 28489 & 7350 & 1498 & 319 & 404125 \\
\hline Cocaine use disorders & - & - & - & - & 638 & 10334 & 38838 & 23083 & 16682 & 5023 & 984 & 237 & 95818 \\
\hline $\begin{array}{l}\text { Amphetamine use } \\
\text { disorders }\end{array}$ & - & - & - & - & 5856 & 25306 & 86702 & 65420 & 17058 & 1765 & 101 & 11 & 202219 \\
\hline $\begin{array}{l}\text { Other mental disorders } \\
\text { with excess deaths* }\end{array}$ & 1136 & 12821 & 80771 & 110192 & 214234 & 336637 & 806074 & 871155 & 759926 & 556262 & 317845 & 493689 & 4560741 \\
\hline Total & 4649 & 26307 & 91451 & 153236 & 545220 & 1032000 & 2364057 & 2285150 & 2290545 & 1716881 & 901329 & 2148447 & 13559272 \\
\hline
\end{tabular}

Note: larger than expected numbers in the $75+$ age group may be an artefact of age groupings.

${ }^{*}$ Disorders with all-cause excess mortality but no cause-specific mortality (bipolar, autistic disorder, major depression and intellectual disability). 
Table 3. MNSDs included as risk factors in GBD 2010 CRAs with attributable YLLs for health outcomes in 2010

\begin{tabular}{|c|c|c|}
\hline Risk & Outcome & $\begin{array}{l}\text { YLLs in thousands } \\
\qquad(95 \% \mathrm{CI})\end{array}$ \\
\hline Alcohol use & $\begin{array}{l}\text { Alcohol use disorders, tuberculosis, lower respiratory infections, } \\
\text { multiple cancers, cardiovascular and circulatory diseases, } \\
\text { cirrhosis of the liver, pancreatitis, epilepsy, diabetes mellitus, } \\
\text { injuries and interpersonal violence* }\end{array}$ & 78706 (70 946-86 778) \\
\hline Injecting drug use & $\begin{array}{l}\text { HIV/AIDS, Hepatitis B and C, liver cancer and cirrhosis of the } \\
\text { liver secondary to hepatitis }\end{array}$ & 7233 (5646-9693) \\
\hline $\begin{array}{l}\text { Mental and substance use } \\
\text { disorders }\end{array}$ & Suicide & $22504(14804-29783)$ \\
\hline Major depression & Ischaemic heart disease & $3573(1791-5412)$ \\
\hline Cannabis dependence & Schizophrenia & Nil \\
\hline
\end{tabular}

*Source: Table 1. From Lim, Vos, Flaxman et al. A comparative risk assessment of burden of disease and injury attributable to 67 risk factors and risk factor clusters in 21 regions, 1990-2010: a systematic analysis for the Global Burden of Disease Study 2010. The Lancet no. 380 (9859):2224-2260.

contributors to other health outcomes. Given the large estimate of mortality-related burden attributed to alcohol dependence, it is expected that, when aggregating YLLs, the regions with the largest attributable burden will be those which have highest rates of alcohol dependence, i.e., Eastern Europe and Central Asia. Sub-Saharan Africa experiences large communicable disease YLLs attributable to alcohol dependence as a result of the continuing high prevalence of communicable disease in relation to other regions.

By incorporating the additional YLLs estimated using CRAs into the overall contribution of mental, substance use and neurological disorders to all cause YLLs (Table 4) we can see a dramatically different picture to that painted in Appendix 1 where YLL contributions appeared negligible in many cases.

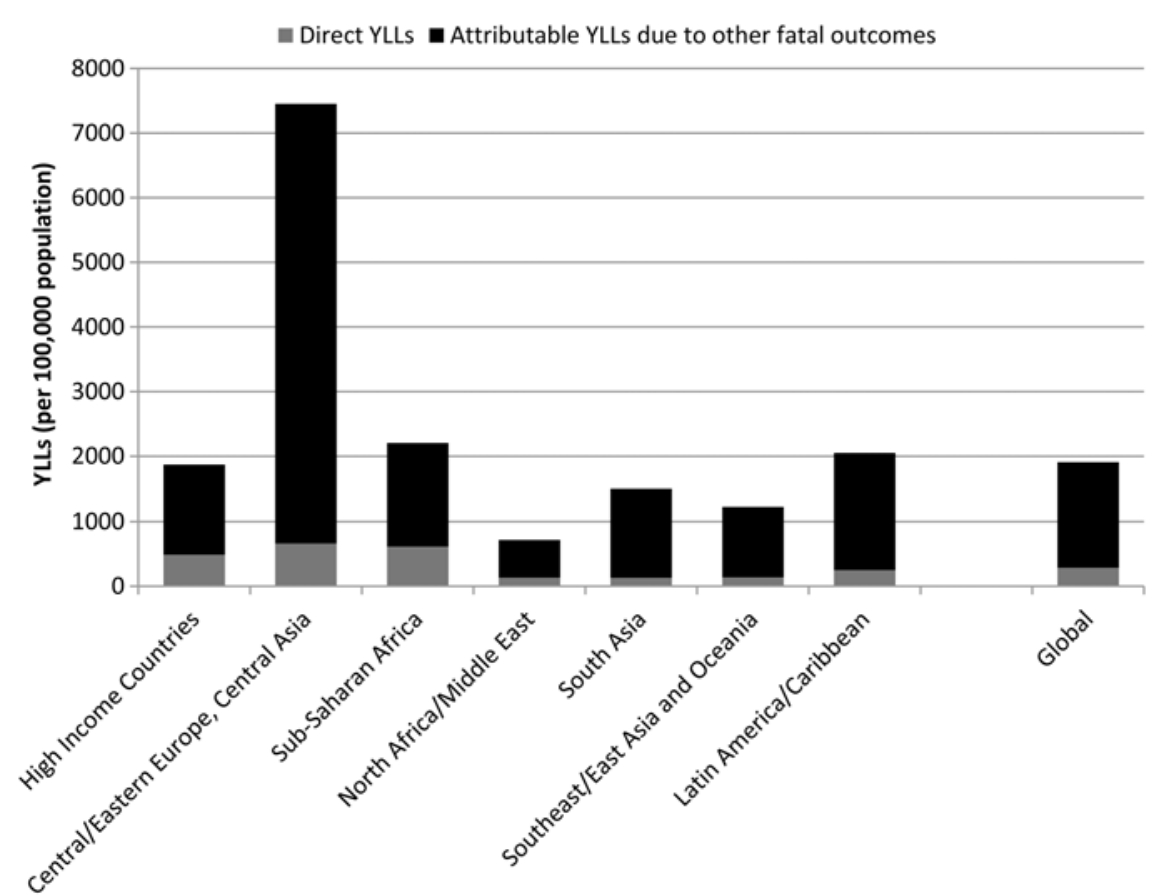

Fig. 6. YLL rates (per 100000 population) for deaths directly associated with MNSDs and indirect deaths for MNSDs as risk factors for other health outcomes, 2010. Note: Indirect deaths include deaths attributable to alcohol and drug use from CRA study; suicide deaths attributable to mental and substance use disorders; and ischaemic heart disease deaths attributable to major depression (see Table above for specific fatal outcomes) 
Table 4. Revised MNS disorder YLLs (per 100000 population) as a \% of all cause YLLs after the inclusion of CRA burden estimates

\begin{tabular}{lcccc}
\hline Region & Direct YLLs & $\begin{array}{c}\text { Attributable YLLs due to } \\
\text { other fatal outcomes }\end{array}$ & $\begin{array}{c}\text { Total } \\
\text { Percentage of all } \\
\text { cause YLLs (\%) }\end{array}$ \\
\hline High income countries & 487 & 1384 & 1871 & 20 \\
Central/Eastern Europe, Central Asia & 661 & 6791 & 7452 & 34 \\
Sub-Saharan Africa & 613 & 1591 & 2204 & 5 \\
North Africa/Middle East & 132 & 584 & 716 & 4 \\
South Asia & 130 & 1380 & 1510 & 5 \\
Southeast/East Asia and Oceania & 137 & 1090 & 1227 & 7 \\
Latin America/Caribbean & 248 & 1803 & 2051 & 10 \\
Global & 286 & 1622 & 1908 & 8 \\
\hline
\end{tabular}

Contributions across regions vary in accordance with the epidemiological profile of disorders within each region, not only of mental, substance use and neurological disorders but also the health outcomes assessed in CRAs. For example, the relatively large contribution in HICs and Central/Eastern Europe and Central Asia likely to be reflective not only of high prevalence of substance use, but also of cardiovascular disease (CVD) which was assessed as an outcome of major depression and alcohol use. In contrast, the relatively lower contribution in sub-Saharan Africa is likely reflective of comparatively lower rates of both substance use disorders (risk factors) and chronic diseases such as CVD (health outcomes). If neurological disorders were assessed as risk factors for other health outcomes using CRAs this picture may have looked different for sub-Saharan Africa where YLLs attributable to neurological disorders is higher than in other regions in the world.

\section{Discussion}

A relatively small YLL burden was attributable to MNSDs in GBD 2010; however, numbers of excess deaths derived from natural history of disease models clearly demonstrate the high degree of mortality associated with these disorders. Quantifying the independent contributions of mental and substance use disorders to poor health outcomes through methods such as the CRA is restricted by data availability and methodological challenges such as establishing causal relationships (Baxter et al. 2011a); nevertheless, there is a growing body of literature which can help us develop hypotheses around these contributions by observing the risks associated with excess death in individuals with mental and substance use disorders.

The relationship between mental disorders and suicide has long been recognised (Li et al. 2011). Mental disorders have also been linked to higher rates of death due to coronary heart disease, stroke, type II diabetes, respiratory diseases and some cancers (Hoyer et al. 2000; Crump et al. 2013). The relationship between mental disorders and physical disease, leading to premature death, is complex. People with mental disorders have an increased risk of death in several ways, for example people with MDD are more likely to develop CVD (Charlson et al. 2011). Psychotropic medications can negatively impact on cardiovascular and metabolic health (De Hert et al. 2012). Obesity and metabolic disturbances are primary risk factors for CVD and type II diabetes, and are two- to threefold more common in people with mental disorders compared with the general population (Scott \& Happell, 2011). Major modifiable risk factors for chronic disease, such as smoking (Lawrence et al. 2009), poor diet and physical inactivity (Kilbourne et al. 2007; Shatenstein et al. 2007) and substance abuse (Scott \& Happell, 2011), are overrepresented in people with mental disorders and these may be consequences of symptoms of MNSDs, medication effects and poor emotional regulation (Scott et al. 2013).

Interestingly, while schizophrenia was the condition among these mental disorder among for which YLLs were attributed, the number of YLLs were very small compared with the excess mortality associated with the disorder. Our finding of high excess mortality in people with schizophrenia is in line with that found in the previous research (Laursen, 2011; Crump et al. 2013; Lawrence et al. 2013). Data linkage studies have shown that the majority of deaths in people with schizophrenia are due to chronic disease with CVD accounting for more than one-third of all premature deaths, while unnatural causes, including suicide, homicide and accidents account for just under 15\% of excess deaths (Crump et al. 2013; Lawrence et al. 2013). Despite concerns over the side-effects of antipsychotic medication, lack of antipsychotic treatment has been linked with higher all-cause mortality rates (HR 1.45, 95\% confidence interval (CI) 1.20-1.76), 
with highest risks attributed to cancer (HR 1.94, 95\% CI 1.13-3.32) and suicide (HR 2.07, 95\% CI 0.73-5.87; Crump et al. 2013). Poly-pharmacy and discontinuation of medication also appear to increase risk of allcause death (Joukamaa et al. 2006; Haukka et al. 2008).

Research from the UK suggests that the excess mortality rate in schizophrenia and bipolar disorder are comparable (Chang et al. 2011). In a recent study, it was estimated that about $80 \%$ of premature death in people with bipolar disorder is due to physical disease, almost half of which is explained by CVD (Westman et al. 2013). Just under $20 \%$ of premature deaths were explained by unnatural causes (suicide, homicide and unintentional injuries; Westman et al. 2013).

People with developmental disorders are at twice the risk of premature death compared with the general population (Mouridsen et al. 2008). Elevated death rates in autistic spectrum disorders (ASD) are due to several causes, including accidents, respiratory diseases and seizures (Shavelle et al. 2001; Mouridsen et al. 2008). The elevated mortality risk associated with ASD may be due more to the presence of comorbid medical conditions, particularly epilepsy, and intellectual disability rather than ASD itself (Lee et al. 2008; Bilder et al. 2013).

Individuals with intellectual disability are expected to have, on average, a life expectancy of 7-12 years less than the general community and life expectancy is dramatically lower in those more severe disability and those with a genetic disorder (e.g., Down syndrome) (Bittles et al. 2002). Intellectual disability is associated with greater tendency towards obesity and physical inactivity compared with the general population, and enhanced predisposition to mental disorders, osteoporosis, thyroid disorders, non-ischaemic heart disease and early onset of dementia (Bittles et al. 2002). In HIC, causes of death in people with intellectual disability are generally coded under congenital abnormalities, diseases of the nervous system and sense organs, mental disorders and respiratory disease (Tyrer \& McGrother, 2009). Information on causes of death in LMIC populations is sparse.

Children with ADHD or CD are two to three times more likely to experience unintentional injuries requiring medical attention compared with children without behavioural disorders (Rowe et al. 2004; Lee et al. 2008). The injuries most commonly reported included burns, poisoning and frac(Rowe et al. 2004). Adolescents and young adults with inattention disorders are more likely to be involved in traffic accidents (Jerome et al. 2006). Adults who were identified with behavioural disorders in childhood are at higher risk of cigarette smoking, binge-drinking (ADHD) and obesity (CD) (von Stumm et al. 2011) in later life. Despite the strong evidence for an association between childhood behavioural disorders and poorer health outcomes, there is insufficient information available to model the natural history of disease and thus no estimates quantifying excess mortality in this group at population level.

Another important disorder demonstrating an apparent absence of excess-mortality in GBD 2010 is the umbrella anxiety disorders group. This was a necessary choice as the information on excess mortality in anxiety disorders was found to be inconsistent with some anxiety disorders; however, severe presentations such as post-traumatic stress disorder (PTSD), have previously been associated with increased deaths caused by ischaemic heart disease (IHD), neoplasms and intentional and unintentional injuries (Ahmadi et al. 2011; Lawrence et al. 2013).

While light-to-moderate alcohol consumption has been associated with lower rates of some disease such as diabetes mellitus and coronary heart disease, heavy consumption has been associated with increased rates of chronic disease, including cancer, MNSDs, cardiovascular disease, liver and pancreas diseases (Rehm et al. 2010a). There is evidence for alcohol as a carcinogen in humans, with particularly strong causal links established between alcoholic beverage consumption and oral cavity, pharynx, larynx, oesophagus, liver, colorectal and female breast cancers (Rehm et al. 2010a). A consistent relationship has also been found between heavy alcohol consumption and epilepsy (Rehm et al. 2010a) and it is also implicated in development of depression and personality disorders, although the direction of causality and effect of confounding factors remains uncertain (Rao et al. 2000; Rohde et al. 2001). Risk of diabetes mellitus, hypertension, stroke, sudden cardiac death and other cardiovascular outcomes is elevated in those with alcohol use disorders (Rehm et al. 2010a). The relationship between alcohol consumption and liver cirrhosis is well recognised, but alcohol use disorders appear more strongly related to cirrhosis mortality $v$. morbidity as it negatively affects the course of existing liver disease (Rehm et al. 2010b). Heavy alcohol use is also related to higher rates of infectious diseases, such as tuberculosis, and unintentional and intentional injury, with strong evidence for a dose-response relationship (Rehm et al. 2010a).

Excess and premature deaths in illicit drug users occur in several ways. Most obvious is the acute toxic effects of illicit drug use which may lead to overdose - the cause-specific deaths generally captured by the ICD-coding system. In addition, a substantial number of deaths are likely due to the more indirect effects of intoxication resulting in accidental injuries and violence. There are a plethora of adverse health outcomes with elevated risks of premature mortality for which illicit drug dependence is an important contributor. These outcomes are often chronic and include 
cardiovascular disease, liver disease and a range of mental disorders including psychosis. Suicide is an important outcome, particularly for opioid users where an SMR of approximately 14 has been reported in two separate reviews (Degenhardt et al. 2011; Chesney et al. 2014). Injection of drugs, most common in opioid dependence, carries a high risk of bloodborne bacterial and viral infections, notably HIV, Hepatitis B and Hepatitis C (Mathers et al. 2010; Nelson et al. 2011).

Epilepsy is associated with two- to threefold higher than mortality in the general community, particularly in childhood onset epilepsy, with the highest standardised mortality ratio encountered in the first year or two after diagnosis (Preux \& Druet-Cabanac, 2005; Sillanpaa \& Shinnar, 2010; Neligan et al. 2010; Trinka et al. 2013). Common causes of premature mortality in epilepsy include acute symptomatic disorders (e.g., brain tumour and stroke), sudden unexpected death, suicide and accidents (Hitiris et al. 2007). Roughly $85 \%$ of people with epilepsy live in LMICs and here the risk of premature mortality is highest (Carpio et al. 2005; Diop et al. 2005; Newton \& Garcia, 2012; Jette \& Trevathan, 2014) from status epilepticus, drowning and burns associated with poor access to and/or compliance with medical treatment, cognitive impairment and age (Jilek \& Rwiza, 1992; Kamgno et al. 2003; Mu et al. 2011; Ngugi et al. 2014).

As with mental disorders, excess mortality in dementia has been associated with functional disability leading to lifestyle factors (e.g., poor eating behaviours, physical inactivity and poor hygiene) and comorbid or underlying physical conditions, including cardiovascular disease, diabetes mellitus and neoplasms (Guehne et al. 2005; Llibre Rodríguez et al. 2008). Infections, particularly pneumonia and the complications of urinary tract infections, frequently lead to death in people with dementia (Mitchell et al. 2009).

Strategies for reducing mortality associated with MNSDs are primarily related to preventing onset of disorders, reducing case fatality, and preventing onset of fatal sequela. There is growing evidence that excess mortality in people in mental and substance use disorders can be reduced through existing evidence-based treatments and improved screening and treatment for chronic disease. There is some evidence that collaborative care by community-based health teams has the potential to reduce overall death as well as suicide deaths (Malone et al. 2007; Dieterich et al. 2010). The use of collaborative care models to improve physical health in people with MNSDs is growing in developed countries and these have demonstrated a range of positive health outcomes including reduced cardiovascular risk profiles (Druss et al. 2010). The effectiveness of these strategies in preventing premature mortality in LMIC populations has yet to be tested but this may be a costeffective approach to treatment where trained mental health clinicians are scarce.

To improve life expectancy in people with comorbid mental and physical health issues requires proactive screening and adequate care for chronic disease. Screening and prevention of metabolic risk factors is essential. Strategies for early cancer detection should be prioritised and models of care developed to ensure that people with MNSDs receive the same level of physical health care and treatment as the rest of the population.

Psychiatric treatments, specifically pharmacotherapies, may have some protective effect against excess mortality (Weinmann et al. 2009) although evidence suggests that this depends on use of medications according to best practice guidelines (Cullen et al. 2013). In contrast, some second generation antipsychotics may actually pose an elevated risk mediated by metabolic side effects (Newcomer, 2005; Smith et al. 2008; Rummel-Kluge et al. 2010).

Much of the disease burden due to opioid dependence and injecting drug use could be averted by scaling up needle and syringe programs (NSPs), opioid substitution treatment and HIV antiretroviral therapy (Degenhardt et al. 2010; Turner et al. 2011). Both methadone and buprenorphine (the two most commonly used medications) have been listed on the WHO's List of Essential Medicines (World Health Organization, 2005) as core medications for the treatment of opioid dependence (Mattick et al. 2008, 2009). OST reduces mortality among opioid-dependent people (Davoli et al. 1994; Caplehorn \& Drummer, 1999; Brugal et al. 2005; Darke et al. 2006; Gibson et al. 2008; Degenhardt et al. $2009 b$ ), with time spent in treatment halving mortality compared with that in time spent out of treatment (Degenhardt et al. 2011). A large evaluation study in multiple countries, including LMICs, has demonstrated that OST is effective in reducing opioid use and injecting risk behaviours and improving physical and mental wellbeing (Lawrinson et al. 2008). There is increasing evidence that not only HIV (Degenhardt et al. 2010) but also HCV (Turner et al. 2011) burden can been reduced through NSPs; HCV burden can also be decreased by effectively treating chronic HCV (Turner et al. 2011). The release of more effective and less toxic $\mathrm{HCV}$ drugs is expected to dramatically improve what have been extremely low rates of HCV treatment uptake by people who inject drugs (Swan, 2011).

There is also scope for reducing the risk of overdose among people who continue to use opioids. There is increasing evidence that the provision of the opioid antagonist naloxone to opioid users enables peers to effectively intervene if overdoses occur (Galea et al. 
2006; Sporer \& Kral, 2007). Additional strategies may include: education of users about the risks of overdose (especially high risk periods such as post-release from prison or after a period of abstinence), and motivational interviews with users who have recently overdosed (Sporer, 2003). Safe injecting rooms have been proposed as an additional strategy to reduce overdose, although their population reach is likely to be more limited (Hall \& Kimber, 2005). There is evidence that psychosocial interventions including self-help programmes and cognitive behavioural therapy are effective in psychostimulant dependence (Baker et al. 2005; Knapp et al. 2007).

In low-income regions, mortality in epilepsy patients is largely due to preventable causes (Diop et al. 2005; Jette \& Trevathan, 2014). Yet, the treatment gap is more than $75 \%$ in low-income countries, and more than $50 \%$ in many lower and upper middle-income countries (Jette \& Trevathan, 2014). Legislation to ensure availability of affordable and efficacious antiseizure medications, clinician education in prescribing antiepileptic medications, and patient education regarding the importance of medical adherence is critical to alleviate the epilepsy treatment gap. Cost-effective epilepsy treatments are available and accurate diagnosis can be made without costly technical equipment. Targeting epilepsy risk factors, including more common structural and metabolic causes of epilepsy will likely decrease mortality risk as well. In addition, education and information provision on safe lifestyle habits in epilepsy patients (i.e., avoiding fires, swimming and driving in those with active convulsive epilepsy) will clearly be beneficial. Education to dispel myths associated with epilepsy among employers and teachers may empower those with epilepsy to seek treatment.

Mortality in dementia patients is commonly by preventable medical conditions, including infections. Caregiver education and support services regarding proper care of patients with cognitive decline will likely decrease infection rates and thus, mortality. Government financial support for healthcare services and caregiver support would also benefit this population. Strategies to enhance nutrition, as well as monitoring and treatment of vascular risk factors including high blood pressure, hypercholesterolemia, smoking, obesity and diabetes, are important measures as well.

\section{Limitations of the study}

Quantifying mortality presents several challenges. Cause of death data is affected by multiple factors, including: certification skills among physicians, diagnostic and other data available for completing the death certificate, cultural variations in choosing and prioritising the cause of death, and institutional parameters for governing mortality reporting (Lozano et al. 2012). In LMIC populations, where many deaths are not medically certified, different data sources and diagnostic approaches are used (e.g., from surveillance systems, psychological autopsy work and disease registries) to derive cause of death estimates (Lozano et al. 2012). The implication is that cause of death assessments are subject to uncertainty; a good illustration is the widely debated difference in maternal death estimates by GBD and by the United Nations (Byass, 2010).

Cause of death data also provided estimates of deaths due to MNSDs that were not captured within the main GBD 2010 categories. The decision was taken to create residual categories to reflect the additional mortality not captured within specific disorders. Deaths and YLLs were calculated for: 'other' mental disorders (16 140 deaths equating to 5.4 YLLs per 100000 persons); 'other' drug use disorders (33,561 deaths equating to 22.5 YLLs per 100000 persons); and 'other' neurological disorders (481 142 deaths and 231.6 YLLs per 100 000). The modelling strategies for these residual groups do not allow calculation of excess mortality for comparison as done throughout this paper however the YLL estimates for these groups are exceptionally high.

Mortality directly related to MNSDs is particularly difficult to capture in cause of death data due to the complex web of causality which link them with other physical disorders. Thus it becomes very important to identify and quantify the not inconsiderable excess premature mortality in people with MNSDs through understanding the pathway between these disorders and fatal sequelae.

Although valuable, the CRAs undertaken as part of GBD 2010 provide an incomplete picture. There are almost certainly deaths where we may not have enough information to parse out what is causally related or what is due to confounding. Assuming multiple risk factors are independent of each other is also a limitation as done in CRA methodology. A more accurate quantification of the joint effects of multiple risk factors, that is what explains the difference between excess and cause-specific deaths, is an important area for future research.

\section{Conclusion}

Despite the challenges in quantifying causal mortality in MNSDs it is abundantly clear that the mortalityassociated disease burden of mental, substance use and neurological disorders is significant. The continuing life expectancy gap in persons with these disorders 
represents a lack of parity between this portion of the population and the community in general (Thornicroft, 2013). People with MNSDs face additional barriers to physical health care because of stigma within the healthcare system, the 'silo' effect between mental and physical health care caused by overspecialisation, and diagnostic overshadowing of physical health issues by presence of mental disorders (Bailey et al. 2013). Differential access to 'usual' care for this group leads to poorer outcomes in terms of health loss and mortality and incurs high costs in health care provision (Centre for Mental Health, 2010). Further research and development of new strategies for reducing mortality associated with MNSDs is needed.

\section{Supplementary material}

The supplementary material referred to in this article can be found at http://www.journals.cambridge.org/ EPS.

\section{Acknowledgements}

The authors gratefully acknowledge the support of Disease Control Priorities (3rd Edition) and the Bill \& Melinda Gates Foundation.

\section{Financial support}

Core funding for the Queensland Centre of Mental Health Research is provided by the Queensland Department of Health. The funders had no role in study design, data collection and analysis, decision to publish or preparation of the manuscript.

\section{Conflict of Interest}

None.

\section{Ethical Standards}

The authors assert that all procedures contributing to this work comply with the ethical standards of the relevant national and institutional committees on human experimentation and with the Helsinki Declaration of 1975, as revised in 2008.

\section{References}

Ahmadi N, Hajsadeghi F, Mirshkarlo HB, Budoff M, Yehuda R, Ebrahimi R (2011). Post-traumatic stress disorder, coronary atherosclerosis, and mortality. American Journal of Cardiology 108, 29-33.
Bailey S, Thorpe L, Smith G (2013). Whole-person Care: from Rhetoric to Reality. Achieving Parity between Mental and Physical Health. Royal College of Psychiatrists: UK.

Baker A, Lee N, Jenner L (2005). Models of intervention and care for psychostimulant users. Australian Government Department of Health and Ageing, 63-82.

Baxter AJ, Charlson FJ, Somerville AJ, Whiteford HA (2011a). Mental disorders as risk factors: assessing the evidence for the global burden of disease study. BMC Medicine 9, 134.

Baxter AJ, Page A, Whiteford HA (2011b). Factors influencing risk of premature mortality in community cases of depression: a meta-analytic review. Epidemiology Research International 2011, 12.

Baxter AJ, Vos T, Scott KM, Norman RE, Flaxman AD, Blore J, Whiteford HA (2014). The regional distribution of anxiety disorders: implications for the Global Burden of Disease Study, 2010. International Journal of Methods in Psychiatric Research, doi: 10.1002/mpr.1444.

Bilder D, Botts E, Smith K, Pimentel R, Farley M, Viskochil J, Mcmahon W, Block H, Ritvo E, Ritvo R-A, Coon H (2013). Excess mortality and causes of death in autism spectrum disorders: a follow up of the 1980s Utah/ UCLA Autism Epidemiologic Study. Journal of Autism and Developmental Disorders 43, 1196-1204.

Bittles AH, Petterson BA, Sullivan SG, Hussain R, Glasson EJ, Montgomery PD (2002). The influence of intellectual disability on life expectancy. Journal of Gerontology 57A, M470-M472.

Brugal MT, Domingo-Salvany A, Puig R, Barrio G, Garcia De Olalla P, De La Fuente L (2005). Evaluating the impact of methadone maintenance programmes on mortality due to overdose and aids in a cohort of heroin users in Spain. Addiction 100, 981-989.

Byass P (2010). The imperfect world of global health estimates. PLoS Medicine 7, e1001006.

Caplehorn JRM, Drummer OH (1999). Mortality associated with New South Wales methadone programs in 1994: lives lost and saved. Medical Journal of Australia 170, 104-109.

Carpio A, Bharucha NE, Jallon P, Beghi E, Campostrini R, Zorzetto S, Mounkoro PP (2005). Mortality of epilepsy in developing countries. Epilepsia 46, 28-32.

Centre for Mental Health (2010). The Economic and Social Costs of Mental Health Problems in 2009/10 [Online]. London: Centre for Mental Health. Retrieved November 2013 from: http://www.centreformentalhealth.org.uk/pdfs/ Economic_and_social_costs_2010.pdf.

Chang C-K, Hayes RD, Perera G, Broadbent MTM, Fernandes AC, Lee WE, Hotopf M, Stewart R (2011). Life expectancy at birth for people with serious mental illness and other major disorders from a secondary mental health care case register in London. PLoS ONE 6, e19590. doi:10.1371/journal.pone.0019590.

Charlson FJ, Stapelberg N, Baxter AJ, Whiteford H (2011). Should global burden of disease estimates include depression as a risk factor for coronary heart disease? BMC Medicine 9, 47.

Charlson FJ, Moran AE, Freedman G, Norman RE, Stapelberg NJC, Baxter AJ, Vos T, Whiteford HA (2013). 
The contribution of major depression to the global burden of ischaemic heart disease: a comparative risk assessment. BMC Medicine 11, 250.

Chesney E, Goodwin GE, Fazel S (2014). Risks of all-cause and suicide mortality in mental disorders: a meta-review. World Psychiatry 13, 153-160.

Crump C, Winkleby MA, Sundquist K, Sundquist J (2013). Comorbidities and mortality in persons with schizophrenia: a Swedish national cohort study. American Journal of Psychiatry 170, 324-333.

Cullen BA, Mcginty EE, Zhang Y, Dosreis SC, Steinwachs DM, Guallar E, Daumit GL (2013). Guideline-concordant antipsychotic use and mortality in schizophrenia. Schizophrenia Bulletin 39, 1159-1168.

Darke S, Degenhardt L, Mattick RP (eds) (2006). Mortality Amongst Illicit Drug Users. Cambridge University Press: Cambridge.

Davoli M, Forastiere F, Abeni DD, Rapiti E, Perucci CA (1994). Longitudinal and cross-sectional mortality studies in injecting drug users. Journal of Epidemiology and Community Health 48, 101-102.

Degenhardt L, Hall W (2012). Extent of illicit drug use and dependence, and their contribution to the global burden of disease. Lancet 379, 55-70.

Degenhardt L, Hall WD, Lynskey M, Mcgrath J, Mclaren J, Calabria B, Whiteford H, Vos T (2009a). Should burden of disease estimates include cannabis use as a risk factor for psychosis? PLOS Medicine 6, e1000133.

Degenhardt L, Randall D, Hall W, Law M, Butler T, Burns L (2009b). Mortality among clients of a state-wide opioid pharmacotherapy programme over 20 years: risk factors and lives saved. Drug and Alcohol Dependence 105, 9-15.

Degenhardt L, Mathers B, Vickerman P, Rhodes T, Latkin C, Hickman M (2010). Prevention of HIV infection for people who inject drugs: why individual, structural, and combination approaches are needed. Lancet 376, 285-301.

Degenhardt L, Bucello C, Mathers B, Briegleb C, Ali H, Hickman M, Mclaren J (2011). Mortality among regular or dependent users of heroin and other opioids: a systematic review and meta-analysis of cohort studies. Addiction 106, 32-51.

Degenhardt L, Whiteford HA, Ferrari AJ, Baxter AJ, Charlson FJ, Hall WD, Freedman G, Burstein R, Johns N, Engell RE, Flaxman A, Murray CJL, Vos T (2013). Global burden of disease attributable to illicit drug use and dependence: findings from the Global Burden of Disease Study 2010. Lancet 382, 1564-1574.

De Hert M, Detraux J, Van Winkel R, Yu W, Correll CU (2012). Metabolic and cardiovascular adverse effects associated with antipsychotic drugs. Nature Reviews Endocrinology 8, 114-126.

Dieterich M, Irving CB, Park B, Marshall M (2010). Intensive Case Management for Severe Mental Illness. Cochrane Database of Systematic Reviews [Online]. http://onlinelibrary. wiley.com/doi/10.1002/14651858.CD007906.pub2/abstract.

Diop AG, Hesdorffer DC, Logroscino G, Hauser WA (2005). Epilepsy and mortality in Africa: a review of the literature. Epilepsia 46, 33-35.
Druss BG, Von Esenwein SA, Compton MT, Rask KJ, Zhao L, Parker RM (2010). A randomized trial of medical care management for community mental health settings: the Primary Care Access, Referral, and Evaluation (PCARE) study. American Journal of Psychiatry 167, 151-159.

Erskine HE, Ferrari AJ, Nelson P, Polanczyk GV, Flaxman AD, Vos T, Whiteford HA, Scott JG (2013). Research Review: epidemiological modelling of attention-deficit/ hyperactivity disorder and conduct disorder for the Global Burden of Disease Study 2010. Journal of Child Psychology and Psychiatry 54, 1263-1274.

Ferrari AJ, Norman RE, Freedman G, Baxter AJ, Pirkis JE, Harris MG, Page A, Carnahan E, Degenhardt L, Vos T, Whiteford HA (2014). The burden attributable to mental and substance use disorders as risk factors for suicide: findings from the Global Burden of Disease Study 2010. PLOS ONE 9, e91936.

Galea S, Worthington N, Piper TM, Nandi VV, Curtis M, Rosenthal DM (2006). Provision of naloxone to injection drug users as an overdose prevention strategy: early evidence from a pilot study in New York City. Addictive Behaviors 31, 907-912.

Gibson A, Degenhardt L, Mattick RP, Ali R, White J, O'Brien S (2008). Exposure to opioid maintenance treatment reduces long-term mortality. Addiction 103, 462468.

Guehne U, Riedel-Heller S, Angermeyer MC (2005). Mortality in dementia: a systematic review. Neuroepidemiology 25, 153-162.

Hall W, Kimber J (2005). Being realistic about benefits of supervised injecting facilities. Lancet 366, 271-272.

Haukka J, Tiihonen J, Härkänen T, Lönnqvist J (2008). Association between medication and risk of suicide, attempted suicide and death in nationwide cohort of suicidal patients with schizophrenia. Pharmacoepidemiology and Drug Safety 17, 686-696.

Hitiris N, Mohanraj R, Norrie J, Brodie MJ (2007). Mortality in epilepsy. Epilepsy and Behavior 10, 363-376.

Hoyer EH, Mortensen PB, Olesen AV (2000). Mortality and causes of death ina total national sample of patients with affective disorders admitted for the first time between 1973 and 1993. British Journal of Psychiatry 176, 76-82.

Institute of Health Metrics and Evaluation (2013). GBD Compare [Online]. Seattle: University of Washington. http://viz.healthmetricsandevaluation.org/gbd-compare/.

Institute for Health Metrics and Evaluation (2014). What Countries are in Each Region? [Online]. Seattle: University of Washington. Retrieved 29 May 2014 from http://www. healthdata.org/gbd/faq\#Whatcountriesareineachregion?

Jerome L, Segal A, Habinski L (2006). What we know about ADHD and driving risk: a literature review, meta-analysis and critique. Journal of the Canadian Academy of Child and Adolescent Psychiatry 15, 105-125.

Jette N, Trevathan E (2014). Saving lives by treating epilepsy in developing countries. Neurology 82, 552-553.

Jilek AL, Rwiza HT (1992). Prognosis of epilepsy in a rural African community: a 30-year follow-up of 164 patients in a outpatient clinic in rural Tanzania. Epilepsia 33, 645-650. 
Joukamaa M, Heliovaara M, Knekt P, Aromaa A, Raitasalo R, Lehtinen V (2006). Schizophrenia, neuroleptic medication and mortality. British Journal of Psychiatry 188, 122-127.

Kamgno J, Pion SDS, Boussinesq M (2003). Demographic impact of epilepsy in Africa: results of a 10-year cohort study in a rural area of Cameroon. Epilepsia 44, 956-963.

Kilbourne AM, Rofey DL, Mccarthy JF, Post EP, Welsh D, Blow FC (2007). Nutrition and exercise behavior among patients with bipolar disorder1. Bipolar Disorders 9, 443-452.

Knapp PW, Soares B, Farrell M, Silva De Lima M (2007). Psychosocial Interventions for Cocaine and Psychostimulant Amphetamines Related Disorders. Cochrane Database of Systematic Reviews [Online], 2007. http://onlinelibrary.wiley.com/doi/10.1002/14651858. CD003023.pub2/full

Laursen TM (2011). Life expectancy among persons with schizophrenia or bipolar affective disorder. Schizophrenia Research 131, 101-104.

Lawrence D, Mitrou F, Zubrick S (2009). Smoking and mental illness: results from population surveys in Australia and the United States. BMC Public Health 9, 285.

Lawrence D, Hancock KJ, Kisely S (2013). The gap in life expectancy from preventable physical illness in psychiatric patients in Western Australia: retrospective analysis of population based registers. British Medical Journal 2013, f2539.

Lawrinson P, Ali R, Buavirat A, Chiamwongpaet $S$, Dvoryak S, Habrat B, Jie S, Mardiati R, Mokri A, Moskalewicz J, Newcombe D, Poznyak V, Subata E, Uchtenhagen A, Utami DS, Vial R, Zhao C (2008). Key findings from the WHO collaborative study on substitution therapy for opioid dependence and HIV/AIDS. Addiction 103, 1484-1492.

Lee L.-C., Harrington RA, Chang JJ, Connors SL (2008). Increased risk of injury in children with developmental disabilities. Research in Developmental Disabilities 29, 247-255.

Li Z, Page A, Martin G, Taylor R (2011). Attributable risk of psychiatric and socio-economic factors for suicide from individual-level, population-based studies: a systematic review. Social Science and Medicine 72, 608-616.

Lim SS, Vos T, Flaxman AD, Danaei G, Shibuya K, AdairRohani H, Amann M, Anderson HR, Andrews KG, Aryee M, Atkinson C, Bacchus LJ, Bahalim AN, Balakrishnan K, Balmes J, Barker-Collo S, Baxter A, Bell ML, Blore JD, Blyth F, Bonner C, Borges G, Bourne R, Boussinesq M, Brauer M, Brooks P, Bruce NG, Brunekreef B, BryanHancock C, Bucello C, Buchbinder R, Bull F, Burnett RT, Byers TE, Calabria B, Carapetis J, Carnahan E, Chafe Z, Charlson F, Chen H, Chen JS, Cheng AT-A, Child JC, Cohen A, Colson KE, Cowie BC, Darby S, Darling S, Davis A, Degenhardt L, Dentener F, Des Jarlais DC, Devries K, Dherani M, Ding EL, Dorsey ER, Driscoll T, Edmond K, Ali SE, Engell RE, Erwin PJ, Fahimi S, Falder G, Farzadfar F, Ferrari A, Finucane MM, Flaxman S, Fowkes FGR, Freedman G, Freeman MK, Gakidou E, Ghosh S, Giovannucci E, Gmel G, Graham K, Grainger R, Grant B, Gunnell D, Gutierrez HR, Hall W, Hoek HW,
Hogan A, Hosgood III HD, Hoy D, Hu H, Hubbell BJ, Hutchings SJ, Ibeanusi SE, Jacklyn GL, Jasrasaria R, Jonas JB, Kan H, Kanis JA, Kassebaum N, Kawakami N, Khang Y-H, Khatibzadeh S, Khoo J-P, Kok C, Laden F, Lalloo R, Lan Q, Lathlean T, Leasher JL, Leigh J, Li Y, Lin JK, Lipshultz SE, London S, Lozano R, Lu Y, Mak J, Malekzadeh R, Mallinger L, Marcenes W, March L, Marks R, Martin R, McGale P, McGrath J, Mehta S, Mensah GA, Merriman TR, Micha R, Michaud C, Mishra V, Hanafiah KM, Mokdad AA, Morawska L, Mozaffarian D, Murphy T, Naghavi M, Neal B, Nelson PK, Nolla JM, Norman R, Olives C, Omer SB, Orchard J, Osborne R, Ostro B, Page A, Pandey KD, Parry CDH, Passmore E, Patra J, Pearce N, Pelizzari PM, Petzold M, Phillips MR, Pope D, Pope III CA, Powles J, Rao M, Razavi H, Rehfuess EA, Rehm JT, Ritz B, Rivara FP, Roberts T, Robinson C, Rodriguez-Portales JA, Romieu I, Room R, Rosenfeld LC, Roy A, Rushton L, Salomon JA, Sampson U, Sanchez-Riera L, Sanman E, Sapkota A, Seedat S, Shi P, Shield K, Shivakoti R, Singh GM, Sleet DA, Smith E, Smith KR, Stapelberg NJC, Steenland K, Stöckl H, Stovner LJ, Straif K, Straney L, Thurston GD, Tran JH, Van Dingenen R, van Donkelaar A, Veerman JL, Vijayakumar L, Weintraub R, Weissman MM, White RA, Whiteford H, Wiersma ST, Wilkinson JD, Williams HC, Williams W, Wilson N, Woolf AD, Yip P, Zielinski JM, Lopez AD, Murray CJL, Ezzati M (2012). A comparative risk assessment of burden of disease and injury attributable to 67 risk factors and risk factor clusters in 21 regions, 19902010: a systematic analysis for the Global Burden of Disease Study 2010. Lancet 380, 2224-2260.

Llibre Rodríguez J, Valhuerdi A, Sanchez II, Reyna C, Guerra MA (2008). The prevalence, correlates and impact of dementia in Cuba: a 10/66 Group population-based survey. Neuroepidemiology 31, 243-251.

Lozano R, Naghavi M, Foreman K, Lim S, Shibuya K, Aboyans V, Abraham J, Adair T, Aggarwal R, Ahn SY (2012). Global and regional mortality from 235 causes of death for 20 age groups in 1990 and 2010: a systematic analysis for the Global Burden of Disease Study 2010: Supplementary appendix. Lancet 380.

Malone D, Marriott S, Newton-Howes G, Simmonds S, Tyrer P (2007). Community mental health teams (CMHTs) for people with severe mental illnesses and disordered personality. Cochrane Database of Systematic Reviews 3, Art. No.: CD000270. doi: 10.1002/14651858.CD000270.pub2.

Mathers BM, Degenhardt L, Ali H, Wiessing L, Hickman M, Mattick RP, Myers B, Ambekar A, Strathdee SA (2010). HIV prevention, treatment, and care services for people who inject drugs: a systematic review of global, regional, and national coverage. Lancet 375, 1014-1028.

Mattick RP, Kimber J, Breen C, Davoli M (2008). Buprenorphine Maintenance Versus Placebo or Methadone Maintenance for Opioid Dependence. Cochrane Database of Systematic Reviews [Online], 2008. http://onlinelibrary.wiley. com/doi/10.1002/14651858.CD002207.pub4/full

Mattick RP, Breen C, Kimber J, Davoli M (2009). Methadone Maintenance Therapy Versus no Opioid Replacement Therapy for Opioid Dependence. Cochrane Database of 
Systematic Reviews [Online], 2009. http://onlinelibrary.wiley. com/doi/10.1002/14651858.CD002209.pub2/full

Mitchell SL, Teno JM, Kiely DK, Shaffer ML, Jones RN, Prigerson HG, Volicer L, Givens JL, Hamel MB (2009). The clinical course of advanced dementia. New England Journal of Medicine 361, 1529-1538.

Mouridsen SE, Bronnum-Hansen H, Rich B, Isager T (2008). Mortality and causes of death in autism spectrum disorders: an update. Autism 12, 403-414.

Mu J, Liu L, Zhang Q, Si Y, Hu J, Fang J, Gao Y, He J, Li S, Wang W, Wu J, Sander JW, Zhou D (2011). Causes of death among people with convulsive epilepsy in rural West China: a prospective study. Neurology 77, 132-137.

Murray CJL, Vos T, Lozano R, Naghavi M, Flaxman AD, Michaud C, Ezzati M, Shibuya K, Salomon JA, Abdalla S, Aboyans V, Abraham J, Ackerman I, Aggarwal R, Ahn SY, Ali MK, Alvarado M, Anderson HR, Anderson LM, Andrews KG, Atkinson C, Baddour LM, Bahalim AN, Barker-Collo S, Barrero LH, Bartels DH, Basáñez M-G, Baxter A, Bell ML, Benjamin EJ, Bennett D, Bernabé E, Bhalla K, Bhandari B, Bikbov B, Abdulhak AB, Birbeck G, Black JA, Blencowe $\mathrm{H}$, Blore JD, Blyth F, Bolliger I, Bonaventure A, Boufous S, Bourne R, Boussinesq $M$, Braithwaite T, Brayne C, Bridgett L, Brooker S, Brooks P, Brugha TS, Bryan-Hancock C, Bucello C, Buchbinder R, Buckle G, Budke CM, Burch M, Burney P, Burstein R, Calabria B, Campbell B, Canter CE, Carabin H, Carapetis J, Carmona L, Cella C, Charlson F, Chen H, Cheng AT-A, Chou D, Chugh SS, Coffeng LE, Colan SD, Colquhoun S, Colson KE, Condon J, Connor MD, Cooper LT, Corriere M, Cortinovis M, de Vaccaro KC, Couser W, Cowie BC, Criqui MH, Cross M, Dabhadkar KC, Dahiya M, Dahodwala N, Damsere-Derry J, Danaei G, Davis A, Leo DD, Degenhardt L, Dellavalle R, Delossantos A, Denenberg J, Derrett S, Des Jarlais DC, Dharmaratne SD, Dherani M, Diaz-Torne C, Dolk H, Dorsey ER, Driscoll T, Duber H, Ebel B, Edmond K, Elbaz A, Ali SE, Erskine H, Erwin PJ, Espindola P, Ewoigbokhan SE, Farzadfar F, Feigin V, Felson DT, Ferrari A, Ferri CP, Fèvre EM, Finucane MM, Flaxman S, Flood L, Foreman K, Forouzanfar MH, Fowkes FGR, Fransen M, Freeman MK, Gabbe BJ, Gabriel SE, Gakidou E, Ganatra HA, Garcia B, Gaspari F, Gillum RF, Gmel G, Gonzalez-Medina D, Gosselin R, Grainger R, Grant B, Groeger J, Guillemin F, Gunnell D, Gupta R, Haagsma J, Hagan H, Halasa YA, Hall W, Haring D, Haro JM, Harrison JE, Havmoeller R, Hay RJ, Higashi H, Hill C, Hoen B, Hoff man H, Hotez PJ, Hoy D, Huang JJ, Ibeanusi SE, Jacobsen KH, James SL, Jarvis D, Jasrasaria R, Jayaraman S, Johns N, Jonas JB, Karthikeyan G, Kassebaum N, Kawakami N, Keren A, Khoo J-P, King CH, Knowlton LM, Kobusingye O, Koranteng A, Krishnamurthi R, Laden F, Lalloo R, Laslett LL, Lathlean T, Leasher JL, Lee YY, Leigh J, Levinson D, Lim SS, Limb E, Lin JK, Lipnick M, Lipshultz SE, Liu W, Loane M, Ohno SL, Lyons R, Mabweijano J, MacIntyre MF, Malekzadeh R, Mallinger L, Manivannan S, Marcenes W, March L, Margolis DJ, Marks GB, Marks R, Matsumori A, Matzopoulos R, Mayosi BM, McAnulty JH, McDermott MM, McGill N, McGrath J, Medina-Mora
ME, Meltzer M, Mensah GA, Merriman TR, Meyer A-C, Miglioli V, Miller M, Miller TR, Mitchell PB, Mock C, Mocumbi AO, Moffitt TE, Mokdad AA, Monasta L, Montico M, Moradi-Lakeh M, Moran A, Morawska L, Mori R, Murdoch ME, Mwaniki MK, Naidoo K, Nair MN, Naldi L, Venkat Narayan KM, Nelson PK, Nelson RG, Nevitt MC, Newton CR, Nolte S, Norman P, Norman R, O'Donnell M, O'Hanlon S, Olives C, Omer SB, Ortblad K, Osborne R, Ozgediz D, Page A, Pahari B, Pandian JD, Rivero AP, Patten SB, Pearce N, Perez Padilla R, PerezRuiz F, Perico N, Pesudovs K, Phillips D, Phillips MR, Pierce K, Pion S, Polanczyk GV, Polinder S, Pope III CA, Popova S, Porrini E, Pourmalek F, Prince M, Pullan RL, Ramaiah KD, Ranganathan D, Razavi H, Regan M, Rehm JT, Rein DB, Remuzzi G, Richards K (2012).

Disability-adjusted life years (DALYs) for 291 diseases and injuries in 21 regions, 1990-2010: a systematic analysis for the Global Burden of Disease Study 2010. Lancet 380, 21972223.

Neligan A, Bell GS, Shorvon SD, Sander JW (2010). Temporal trends in the mortality of people with epilepsy: a review. Epilepsia 51, 2241-2246.

Nelson PK, Mathers BM, Cowie B, Hagan H, Des Jarlais D, Horyniak D, Degenhardt L (2011). Global epidemiology of hepatitis B and hepatitis C in people who inject drugs: results of systematic reviews. Lancet 378, 571-583.

Newcomer JW (2005). Second-generation (atypical) antipsychotics and metabolic effects. CNS Drugs 19, 1-93.

Newton CR, Garcia HH (2012). Epilepsy in poor regions of the world. Lancet 380, 1193-201.

Ngugi AK, Bottomley C, Fegan G, Chengo E, Odhiambo R, Bauni E, Neville B, Kleinschmidt I, Sander JW, Newton CR (2014). Premature mortality in active convulsive epilepsy in rural Kenya: causes and associated factors. Neurology 82, 582-589.

Park JE, Lee JY, Suh GH, Kim BS, Cho MJ (2014). Mortality rates and predictors in community-dwelling elderly individuals with cognitive impairment: an eight-year follow-up after initial assessment. International Psychogeriatrics 26, 1295-304.

Preux P-M, Druet-Cabanac M (2005). Epidemiology and aetiology of epilepsy in sub-Saharan Africa. Lancet Neurology 4, 21-31.

Prince M, Patel V, Saxena S, Maj M, Maselko J, Phillips MR, Rahman A (2007). No health without mental health. Lancet 370, 859-877.

Rao Um A, Daley SE, Hammen C (2000). Relationship between depression and substance use disorders in adolescent women during the transition to adulthood. Journal of the American Academy of Child and Adolescent Psychiatry 39, 215-222.

Rehm J, Baliunas D, Borges GLG, Graham K, Irving H, Kehoe T, Parry CD, Patra J, Popova S, Poznyak V, Roerecke M, Room R, Samokhvalov AV, Taylor B (2010a). The relation between different dimensions of alcohol consumption and burden of disease: an overview. Addiction 105, 817-843.

Rehm J, Taylor B, Mohapatra S, Irving H, Baliunas D, Patra J, Roerecke M (2010b). Alcohol as a risk factor for liver 
cirrhosis: a systematic review and meta-analysis. Drug and Alcohol Review 29, 437-445.

Rohde P, Lewinsohn PM, Kahler CW, Seeley JR, Brown RA (2001). Natural course of alcohol use disorders from adolescence to young adulthood. Journal of the American Academy of Child and Adolescent Psychiatry 40, 83-90.

Roshanaei-Moghaddam B, Katon W (2009). Premature mortality from general medical illnesses among persons with bipolar disorder: a review. Psychiatric Services 60, 147-156.

Rowe R, Maughan B, Goodman R (2004). Childhood psychiatric disorder and unintentional injury: findings from a national cohort study. Journal of Pediatric Psychology 29, 119-130.

Rummel-Kluge C, Komossa K, Schwarz S, Hunger H, Schmid F, Lobos CA, Kissling W, Davis JM, Leucht S (2010). Head-to-head comparisons of metabolic side effects of second generation antipsychotics in the treatment of schizophrenia: a systematic review and meta-analysis. Schizophrenia Research 123, 225-233.

Salomon JA, Wang H, Freeman MK, Vos T, Flaxman AD, Lopez AD, Murray CJL (2012). Healthy life expectancy for 187 countries, 1990-2010: a systematic analysis for the Global Burden Disease Study 2010. Lancet 380, 2144-2162.

Scott D, Happell B (2011). The high prevalence of poor physical health and unhealthy lifestyle behaviours in individuals with severe mental illness. Issues in Mental Health Nursing 32, 589-597.

Scott KM, Wu B, Saunders K, Benjet C, He Y, Lepine J-P, Tachimori H, Van Korff M (2013). Early-onset mental disorders and their links to chronic physical conditions in adulthood. In The Burdens of Mental Disorders (ed. J Alonso, $\mathrm{S}$ Chatterji and Y He). Global Perspectives from the WHO World Mental Health Surveys. Cambridge University Press: New York, 87-95.

Shatenstein B, Kergoat M-J, Reid I (2007). Poor nutrient intakes during 1-year follow-Uu with community dwelling older adults with early-stage Alzheimer dementia compared to cognitively intact matched controls. Journal of the American Dietetic Association 107, 2091-2099.

Shavelle RM, Strauss DJ, Pickett J (2001). Causes of death in autism. Journal of Autism and Developmental Disorders 31, 569-576.

Sillanpaa M, Shinnar S (2010). Long-term mortality in childhood-onset epilepsy. New England Journal of Medicine 363, 2522-2529.

Smith M, Hopkins D, Peveler RC, Holt RIG, Woodward M, Ismail K (2008). First- v. second-generation antipsychotics and risk for diabetes in schizophrenia: systematic review and meta-analysis. British Journal of Psychiatry 192, 406-411.

Sporer KA (2003). Strategies for preventing heroin overdose. British Medical Journal, 326, 442-444.

Sporer KA, Kral AH (2007). Prescription naloxone: a novel approach to heroin overdose prevention. Annals of Emergency Medicine 49, 172-177.

Swan T (2011). Hepatitis C Treatment Pipeline Report. Treatment Action Group: New York, NY.

Thornicroft G (2013). Premature death among people with mental illness: at best a failure to act on evidence; at worst a form of lethal discrimination. British Medical Journal 346: f3423.

Trinka E, Bauer G, Oberaigner W, Ndayisaba JP, Seppi K, Granbichler CA (2013). Cause-specific mortality among patients with epilepsy: results from a 30-year cohort study. Epilepsia 54, 495-501.

Turner Km E, Hutchinson S, Vickerman P, Hope V, Craine N, Palmateer N, May M, Taylor A, De Angelis D, Cameron S, Parry J, Lyons M, Goldberg D, Allen E, Hickman M (2011). The impact of needle and syringe provision and opiate substitution therapy on the incidence of hepatitis $\mathrm{C}$ virus in injecting drug users: pooling of UK evidence. Addiction 106, 1978-1988.

Tyrer F, Mcgrother C (2009). Cause-specific mortality and death certificate reporting in adults with moderate to profound intellectual disability. Journal of Intellectual Disability Research 53, 898-904.

Von Stumm S, Deary IJ, Kivimäki M, Jokela M, Clark H, Batty GD (2011). Childhood behavior problems and health at midlife: 35-year follow-up of a Scottish birth cohort. Journal of Child Psychology and Psychiatry 52, 992-1001.

Vos T, Flaxman AD, Naghavi M, Lozano R, Michaud C, Ezzati M, Shibuya K, Salomon JA, Abdalla S, Aboyans V, Abraham J, Ackerman I, Aggarwal R, Ahn SY, Ali MK, Alvarado M, Anderson HR, Anderson LM, Andrews KG, Atkinson C, Baddour LM, Bahalim AN, Barker-Collo S, Barrero LH, Bartels DH, Basáñez M-G, Baxter A, Bell ML, Benjamin EJ, Bennett D, Bernabé E, Bhalla $K$, Bhandari $B$, Bikbov B, Bin Abdulhak A, Birbeck G, Black JA, Blencowe $\mathrm{H}$, Blore JD, Blyth F, Bolliger I, Bonaventure A, Boufous S, Bourne R, Boussinesq M, Braithwaite T, Brayne C, Bridgett L, Brooker S, Brooks P, Brugha TS, Bryan-Hancock C, Bucello C, Buchbinder R, Buckle G, Budke CM, Burch M, Burney P, Burstein R, Calabria B, Campbell B, Canter CE, Carabin H, Carapetis J, Carmona L, Cella C, Charlson F, Chen H, Cheng AT-A, Chou D, Chugh SS, Coffeng LE, Colan SD, Colquhoun S, Colson KE, Condon J, Connor MD, Cooper LT, Corriere M, Cortinovis M, de Vaccaro KC, Couser W, Cowie BC, Criqui MH, Cross M, Dabhadkar KC, Dahiya M, Dahodwala N, Damsere-Derry J, Danaei G, Davis A, De Leo D, Degenhardt L, Dellavalle R, Delossantos A, Denenberg J, Derrett S, Des Jarlais DC, Dharmaratne SD, Dherani M, Diaz-Torne C, Dolk H, Dorsey ER, Driscoll T, Duber H, Ebel B, Edmond K, Elbaz A, Ali SE, Erskine H, Erwin PJ, Espindola P, Ewoigbokhan SE, Farzadfar F, Feigin V, Felson DT, Ferrari A, Ferri CP, Fèvre EM, Finucane MM, Flaxman S, Flood L, Foreman K, Forouzanfar MH, Fowkes FGR, Franklin R, Fransen M, Freeman MK, Gabbe BJ, Gabriel SE, Gakidou E, Ganatra HA, Garcia B, Gaspari F, Gillum RF, Gmel G, Gosselin R, Grainger R, Groeger J, Guillemin F, Gunnell D, Gupta R, Haagsma J, Hagan H, Halasa YA, Hall W, Haring D, Haro JM, Harrison JE, Havmoeller R, Hay RJ, Higashi H, Hill C, Hoen B, Hoff man H, Hotez PJ, Hoy D, Huang JJ, Ibeanusi SE, Jacobsen KH, James SL, Jarvis D, Jasrasaria R, Jayaraman S, Johns N, Jonas JB, Karthikeyan G, Kassebaum N, Kawakami N, Keren A, Khoo J-P, King $\mathrm{CH}$, Knowlton LM, Kobusingye O, Koranteng A, 
Krishnamurthi R, Lalloo R, Laslett LL, Lathlean T, Leasher JL, Lee YY, Leigh J, Lim SS, Limb E, Lin JK, Lipnick M, Lipshultz SE, Liu W, Loane M, Ohno SL, Lyons R, Ma J, Mabweijano J, MacIntyre MF, Malekzadeh R, Mallinger L, Manivannan S, Marcenes W, March L, Margolis DJ, Marks GB, Marks R, Matsumori A, Matzopoulos R, Mayosi BM, McAnulty JH, McDermott MM, McGill N, McGrath J, Medina-Mora ME, Meltzer M, Mensah GA, Merriman TR, Meyer A-C, Miglioli V, Miller M, Miller TR, Mitchell PB, Mocumbi AO, Moffitt TE, Mokdad AA, Monasta L, Montico M, Moradi-Lakeh M, Moran A, Morawska L, Mori R, Murdoch ME, Mwaniki MK, Naidoo K, Nair MN, Naldi L, Venkat Narayan KM, Nelson PK, Nelson RG, Nevitt MC, Newton CR, Nolte S, Norman P, Norman R, O'Donnell M, O'Hanlon S, Olives C, Omer SB, Ortblad K, Osborne R, Ozgediz D, Page A, Pahari B, Pandian JD, Rivero AP, Patten SB, Pearce N, Perez Padilla R, Perez-Ruiz F, Perico N, Pesudovs K, Phillips D, Phillips MR, Pierce K, Pion S, Polanczyk GV, Polinder S, Pope III CA, Popova S, Porrini E, Pourmalek F, Prince M, Pullan RL, Ramaiah KD, Ranganathan D, Razavi H, Regan M, Rehm JT, Rein DB, Remuzzi G, Richardson K, Rivara FP, Roberts T,

Robinson C, De Leòn FR (2012). Years lived with disability (YLDs) for 1160 sequelae of 289 diseases and injuries 1990?
2010: a systematic analysis for the Global Burden of Disease Study 2010. Lancet 380, 2163-2196.

Wahlbeck K, Westman J, Nordentoft M, Gissler M, Laursen TM (2011). Outcomes of Nordic mental health systems: life expectancy of patients with mental disorders. British Journal of Psychiatry 199, 453-458.

Weinmann S, Read J, Aderhold V (2009). Influence of antipsychotics on mortality in schizophrenia: systematic review. Schizophrenia Research 113, 1-11.

Westman J, Hallgren J, Wahlbeck K, Erlinge D, Alfredsson L, Osby U (2013). Cardiovascular mortality in bipolar disorder: a population-based cohort study in Sweden. BMJ Open 3, e002373. doi:10.1136/bmjopen-2012002373 .

Whiteford HA, Degenhardt L, Rehm J, Baxter AJ, Ferrari AJ, Erskine HE, Charlson FJ, Norman RE, Flaxman AD, Johns N, Burstein R, Murray CJL, Vos T (2013). Global burden of disease attributable to mental and substance use disorders: findings from the Global Burden of Disease Study 2010. Lancet 382, 1575-1586.

World Health Organization (1993). The ICD-10 Classification of Mental and Behavioral Disorders: Diagnostic Criteria for Research, World Health Organization.

World Health Organization (2005). WHO Model List of Essential Medicines. 